\title{
Dopamine Inhibition Differentially Controls Excitability of Substantia Nigra Dopamine Neuron Subpopulations through T-Type Calcium Channels
}

\author{
DRebekah C. Evans, Manhua Zhu, and Zayd M. Khaliq \\ Cellular Neurophysiology Unit, National Institute of Neurological Disorders and Stroke, National Institutes of Health, Bethesda, Maryland 20892
}

While there is growing appreciation for diversity among ventral tegmental area dopamine neurons, much less is known regarding functional heterogeneity among the substantia nigra pars compacta $(\mathrm{SNc})$ neurons. Here, we show that calbindin-positive dorsal tier and calbindin-negative ventral tier SNc dopaminergic neurons in mice comprise functionally distinct subpopulations distinguished by their dendritic calcium signaling, rebound excitation, and physiological responses to dopamine D2-receptor (D2) autoinhibition. While dopamine is known to inhibit action potential backpropagation, our experiments revealed an unexpected enhancement of excitatory responses and dendritic calcium signals in the presence of D2-receptor inhibition. Specifically, dopamine inhibition and direct hyperpolarization enabled the generation of low-threshold depolarizations that occurred in an all-or-none or graded manner, due to recruitment of T-type calcium channels. Interestingly, these effects occurred selectively in calbindin-negative dopaminergic neurons within the SNc. Thus, calbindin-positive and calbindin-negative SNc neurons differ substantially in their calcium channel composition and efficacy of excitatory inputs in the presence of dopamine inhibition.

Key words: calbindin; dendrites; dopamine; substantia nigra; $t$-type calcium channels; two-photon imaging

Significance Statement

Substantia nigra dopaminergic neurons can be divided into two populations: the calbindin-negative ventral tier, which is vulnerable to neurodegeneration in Parkinson's disease, and the calbindin-positive dorsal tier, which is relatively resilient. Although tonic firing is similar in these subpopulations, we find that their responses to dopamine-mediated inhibition are strikingly different. During inhibition, calbindin-negative neurons exhibit increased sensitivity to excitatory inputs, which can then trigger large dendritic calcium transients due to strong expression of T-type calcium channels. Therefore, SNc neurons differ substantially in their calcium channel composition, which may contribute to their differential vulnerability. Furthermore, T-currents increase excitation efficacy onto calbindin-negative cells during dopamine inhibition, suggesting that shared inputs are differentially processed in subpopulations resulting in distinct downstream dopamine signals.

\section{Introduction}

Dopamine neurons play a critical role in a variety of basic behaviors, including voluntary movement, reward learning, and aversion. Early studies considered midbrain dopamine neurons to be a fairly homogenous population, categorizing them broadly accord-

Received Jan. 13, 2017; revised Feb. 15, 2017; accepted Feb. 21, 2017

Author contributions: R.C.E. and Z.M.K. designed research; R.C.E. and M.Z. performed research; R.C.E. and M.Z. analyzed data; R.C.E. and Z.M.K. wrote the paper.

This work was supported by National Institute of Neurological Disorders and Stroke Intramural Research Program Grant NS003134 to Z.M.K. We thank Sherry Zhang for technical assistance and Rahilla Tarfa, Travis Hage, Fabian Philippart, and HuaYu Ding for discussions on an earlier version of this manuscript.

The authors declare no competing financial interests.

Correspondence should be addressed to Zayd M. Khaliq, Cellular Neurophysiology Unit, National Institute of Neurological Disorders and Stroke, National Institute of Health, Bethesda, MD 20892. E-mail: Zayd.Khaliq@nih.gov.

DOI:10.1523/JNEUROSCI.0117-17.2017

Copyright $\odot 2017$ the authors $\quad 0270-6474 / 17 / 373704-17 \$ 15.00 / 0$ ing to their location within the substantia nigra pars compacta $(\mathrm{SNc})$ or the neighboring ventral tegmental area (VTA). However, recent studies have revealed heterogeneity within these nuclei. Specifically, dopamine neurons of the VTA have been shown to differ in molecular composition (Liu et al., 2014; Poulin et al., 2014), projection pattern (Fallon and Moore, 1978; Aransay et al., 2015), input pattern (Geisler and Zahm, 2005; Ogawa et al., 2014; Beier et al., 2015; Menegas et al., 2015), and electrophysiological characteristics (Neuhoff et al., 2002; Ford et al., 2006; Lammel et al., 2008; Margolis et al., 2008; Zhang et al., 2010; Hnasko et al., 2012). By contrast, much less is known regarding functional heterogeneity among SNc dopaminergic neurons.

The SNc can be divided into two anatomical regions, the dorsal and ventral tiers (Gerfen et al., 1987). The dorsal-most layer of the SNc, or the dorsal tier, contains dopamine neurons that ex- 
press the $\mathrm{Ca}^{2+}$-binding molecule calbindin. The ventral tier lies directly above the substantia nigra reticulata and contains many calbindin-negative (Calb-) dopaminergic neurons. These anatomically and biochemically defined subpopulations have been further distinguished by their susceptibility to neurodegeneration in Parkinson's disease. In particular, Calb- SNc neurons of the ventral tier are highly vulnerable to cell death in the brains of Parkinson's patients, while calbindin-positive (Calb+) neurons of the dorsal tier tend to be resilient (Yamada et al., 1990; Damier et al., 1999). In addition, neurons of the dorsal and ventral tiers differ in their projection patterns: ventral tier neurons project to the dorsal striatum, where they preferentially innervate the patch compartments, while the dorsal tier neurons may innervate the matrix or possibly project to extrastriatal regions (Gerfen et al., 1987; Prensa and Parent, 2001; Bentivoglio and Morelli, 2005; Matsuda et al., 2009; Dopeso-Reyes et al., 2014). A significant physiological study reported differences in the hyperpolarization cation current $\left(I_{\mathrm{h}}\right.$; Neuhoff et al., 2002). A separate study of cultured lateral and medial mesencephalic dopamine neurons (putative SNc/Calb - and VTA/Calb + cells) found that SNc/ Calb - neurons show increased mitochondrial stress (Dryanovski et al., 2013). Given the importance of these cell types under normal and pathological conditions, a clearer understanding of the physiological characteristics that distinguish these two cells types is necessary.

Dopamine neurons undergo autoinhibitory responses to somatodendritically released dopamine (Beckstead et al., 2004; Gantz et al., 2013). Somatic and dendritic D2-autoreceptors activate G-protein-coupled inwardly rectifying potassium (GIRK) channels that hyperpolarize neurons, resulting in the inhibition of tonic firing (Lacey et al., 1990). Studies of dendritic excitability in SNc neurons have shown that dopamine gates action potential (AP) backpropagation (Gentet and Williams, 2007). Specifically, GIRK-mediated hyperpolarization recovers A-type potassium channels, which inhibit spike backpropagation, and compartmentalizes dendritic signaling. Furthermore, direct voltage-clamp recordings of somatic voltage-gated calcium $\left(\mathrm{Ca}^{2+}\right)$ currents show that dopamine modulation results in inhibition of high-threshold $\mathrm{Ca}^{2+}$ channels (Cardozo and Bean, 1995). Together, these results suggest that that the role of dopamine is to cause inhibition of dendritic excitability, but direct dendritic $\mathrm{Ca}^{2+}$ imaging has not previously been performed.

Here, our experiments reveal that dopamine inhibition surprisingly leads to an enhancement of dendritic responses to excitation as well as enhancement of dendritic $\mathrm{Ca}^{2+}$ signals selectively in Calbventral tier SNc dopamine neurons. This is due to a recruitment of subthreshold T-type $\mathrm{Ca}^{2+}$ channels expressed at higher densities in Calb- neurons. In addition to large all-or-none regenerative events, we show that moderate hyperpolarization produced by D2-receptor activation results in the graded amplification of depolarization. Therefore, we present the first evidence that the $\mathrm{Ca}^{2+}$ channel composition differs between the dorsal tier Calb + and ventral tier Calb-SNc subpopulations. In addition, this study provides clear physiological evidence that dorsal tier $\mathrm{Calb}+$ and ventral tier Calb- SNc dopaminergic neurons comprise functionally distinct subpopulations distinguished by their responses to dopamine D2receptor autoinhibition.

\section{Materials and Methods}

Animal use. All animal handling and procedures were approved by the Animal Care and Use Committee for the National Institute of Neurological Disorders and Stroke at the National Institutes of Health. Tyrosine hydroxylase-GFP (TH-GFP; C57B6 background) mice and calbindin-cre/
Td-tomato mice [Calb1-2A-dgCre-D/Ai9(RCL-tdT); Zeng, 2013] of either sex were used at age postnatal day (P) 13-P24 except where adult ( $>6$ week old) mice are specified. The calbindin-cre mice express a destabilized cre selectively in calbindin-containing neurons. To stabilize the cre and drive expression of td-tomato, intraperitoneal injections of trimethoprim (Sigma-Aldrich) were given at $170 \mu \mathrm{g} / \mathrm{g}$ (Sando et al., 2013). Young mice were always given one injection, while some adult mice were given the same dose of trimethoprim injections on 2 consecutive days. These mice were used for electrophysiology and $\mathrm{Ca}^{2+}$ imaging 3-10 d after injection. Costaining for calbindin in these mice showed that not all stained neurons were td-tomato-positive $(\sim 50 \%)$. However, to increase the likelihood of patching Calb- dopamine neurons in these mice, we chose neurons located at the border of the compacta and reticulata, where Calb + neurons are not present (Fig. 1A). Because of this, we considered all td-tomato-labeled neurons to be Calb + and unlabeled neurons to be largely Calb-. Wild-type (Swiss-Webster) mice were used where specified.

Slicing and electrophysiology. Mice were anesthetized with isoflurane and decapitated. For young mice, brains were extracted to ice-cold modified ACSF containing (in mM) the following: 250 glycerol, $2.5 \mathrm{KCl}, 2$ $\mathrm{MgCl}_{2}, 2 \mathrm{CaCl}_{2}, 1.2 \mathrm{NaH}_{2} \mathrm{PO}_{4}, 10$ HEPES, $21 \mathrm{NaHCO}_{3}$, and 5 glucose. Sagittal slices were cut $300 \mu \mathrm{m}$ thick and incubated for $30 \mathrm{~min}$ in heated $\left(34^{\circ} \mathrm{C}\right)$ ACSF containing (in mM) the following: $125 \mathrm{NaCl}, 25 \mathrm{NaHCO}_{3}$, $1.25 \mathrm{NaH}_{2} \mathrm{PO}_{4}, 3.5 \mathrm{KCl}, 10$ glucose, 5 HEPES, $1 \mathrm{MgCl}_{2}$, and $2 \mathrm{CaCl}_{2}$. Adult mice were anesthetized with isoflurane and transcardially perfused with ice-cold modified ACSF containing (in $\mathrm{mM}$ ) the following: 198 glycerol, $2.5 \mathrm{KCl}, 1.2 \mathrm{NaH}_{2} \mathrm{PO}_{4}, 20$ HEPES, $25 \mathrm{NaHCO}_{3}, 10$ glucose, 10 $\mathrm{MgCl}_{2}, 0.5 \mathrm{CaCl}_{2}, 5 \mathrm{Na}$-ascorbate, $3 \mathrm{Na}$-pyruvate, and 2 thiourea. Sagittal slices were cut $200 \mu \mathrm{m}$ thick and incubated for $30 \mathrm{~min}$ in heated $\left(34^{\circ} \mathrm{C}\right)$ ACSF containing (in $\mathrm{mm}$ ) the following: $92 \mathrm{NaCl}, 30 \mathrm{NaHCO}_{3}, 1.2$ $\mathrm{NaH}_{2} \mathrm{PO}_{4}, 2.5 \mathrm{KCl}, 35$ glucose, 20 HEPES, $2 \mathrm{MgCl}_{2}, 2 \mathrm{CaCl}_{2}, 5 \mathrm{Na}-$ ascorbate, $3 \mathrm{Na}$-pyruvate, and 2 thiourea. Slices were removed to room temperature and used $30 \mathrm{~min}$ to $6 \mathrm{~h}$ later. Whole-cell recordings were made using borosilicate pipettes (2-7 M $\Omega$ ) filled with internal recording solution containing (in $\mathrm{mm}$ ) the following: $122 \mathrm{KMeSO}_{3}, 9 \mathrm{NaCl}, 1.8$ $\mathrm{MgCl}_{2}, 4 \mathrm{Mg}$-ATP, $0.3 \mathrm{Na}$-GTP, 14 phosphocreatine, 9 HEPES, 0.3 Fluo- $5 \mathrm{~F}\left(K_{\mathrm{D}}=\sim 2.3 \mu \mathrm{m}\right)$, and 0.05 AlexaFluor 594 hydrazide adjusted to a $\mathrm{pH}$ value of 7.35 with $\mathrm{KOH}$. Recordings for post hoc immunohistochemistry used internal solution replacing Fluo-5F with 0.45 EGTA and $0.09 \mathrm{CaCl}_{2}$. Current-clamp recordings were manually bridge-balanced. Liquid junction potential $(-8 \mathrm{mV})$ was not corrected. All experiments in adult mice, all voltage-clamp experiments, and all experiments involving synaptic stimulation or rebound firing were conducted heated (30$32^{\circ} \mathrm{C}$ ). The remaining experiments were at room temperature.

Synaptic stimulation was evoked with theta-glass electrodes pulled on a vertical puller and filled with ACSF. Electrodes were placed near, but not against, dendrites. Stimulations were evoked using an Isoflex, amplitudes ranging from 1 to $90 \mathrm{~V}$. Dopamine iontophoresis was conducted using sharp microelectrodes pulled to $40-80 \mathrm{M} \Omega$ resistance containing $1 \mathrm{~m}$ dopamine and placed at the slice surface directly above the soma of the recorded cell. Internal solution for iontophoresis experiments contained 9 mм BAPTA. In parallel experiments without intracellular BAPTA, quinpirole $(10-50 \mu \mathrm{M})$ was puffed onto wild-type neurons using a pneumatic picopump (WPI). In cases when dopamine iontophoresis or quinpirole puff did not hyperpolarize the neuron $\geq-60$ $\mathrm{mV}$, the recording was not included in analysis $(n=3$ of 18,4 of 10 neurons respectively). Voltage-ramp experiments were conducted in the presence of $0.5 \mu \mathrm{M}$ TTX. Series resistance was $\leq 25 \mathrm{M} \Omega$ and was compensated $40-60 \%$.

Two-photon calcium imaging. Two-photon $\mathrm{Ca}^{2+}$ imaging was performed using previously published procedures (Hage and Khaliq, 2015). Briefly, cells were imaged on a two-photon microscope (Brucker) with a Mai Tai ultrafast Ti:sapphire laser (Spectra-Physics) tuned to $810 \mathrm{~nm}$. A $575 \mathrm{~nm}$ dichroic long-pass mirror was used to split the fluorescence signal through $607 / 45 \mathrm{~nm}$ and $525 / 70 \mathrm{~nm}$ filters to the multialkali photomultiplier tubes (Hamamatsu). $\mathrm{Ca}^{2+}$ signals were quantified as the ratio of green $\left(\mathrm{Ca}^{2+}\right.$ sensitive) to red (stable) signal. The green/red $(G / R)$ ratio was normalized by the ratio of saturated $\left(2 \mathrm{mM} \mathrm{Ca}^{2+}\right)$ green $(G s)$ to red signal measured daily via a pipette placed at the surface of the 

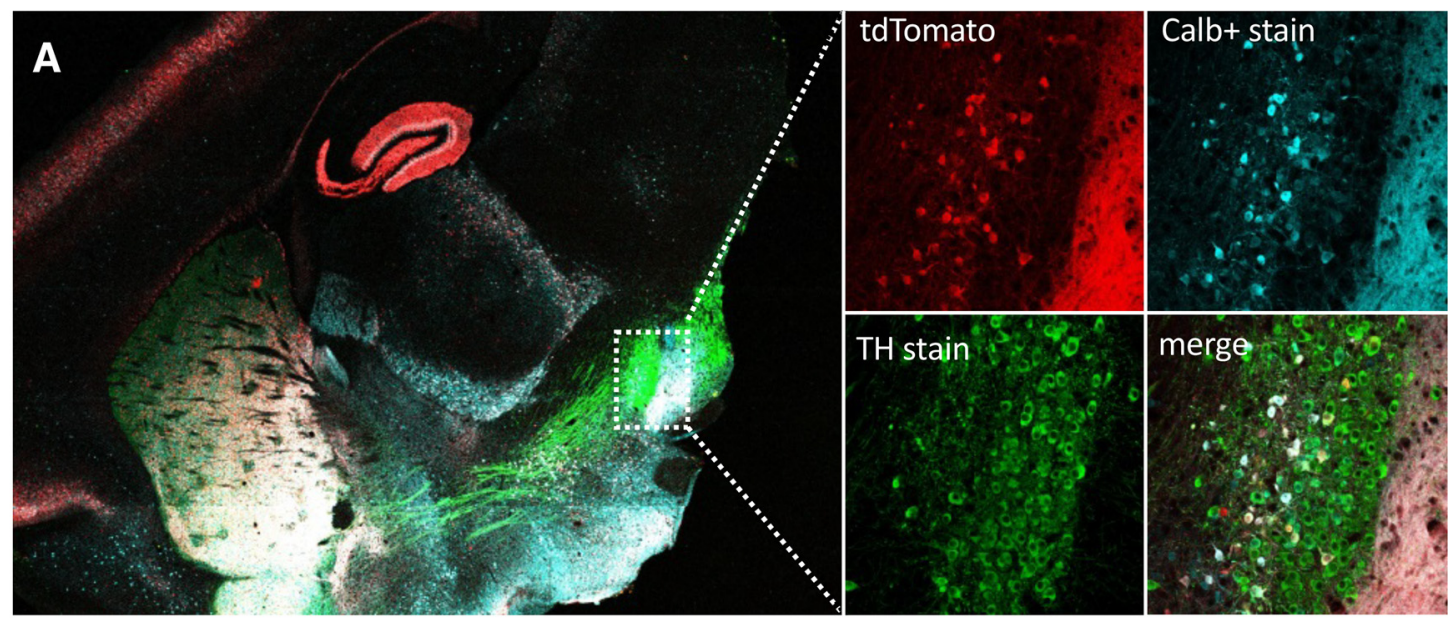

B
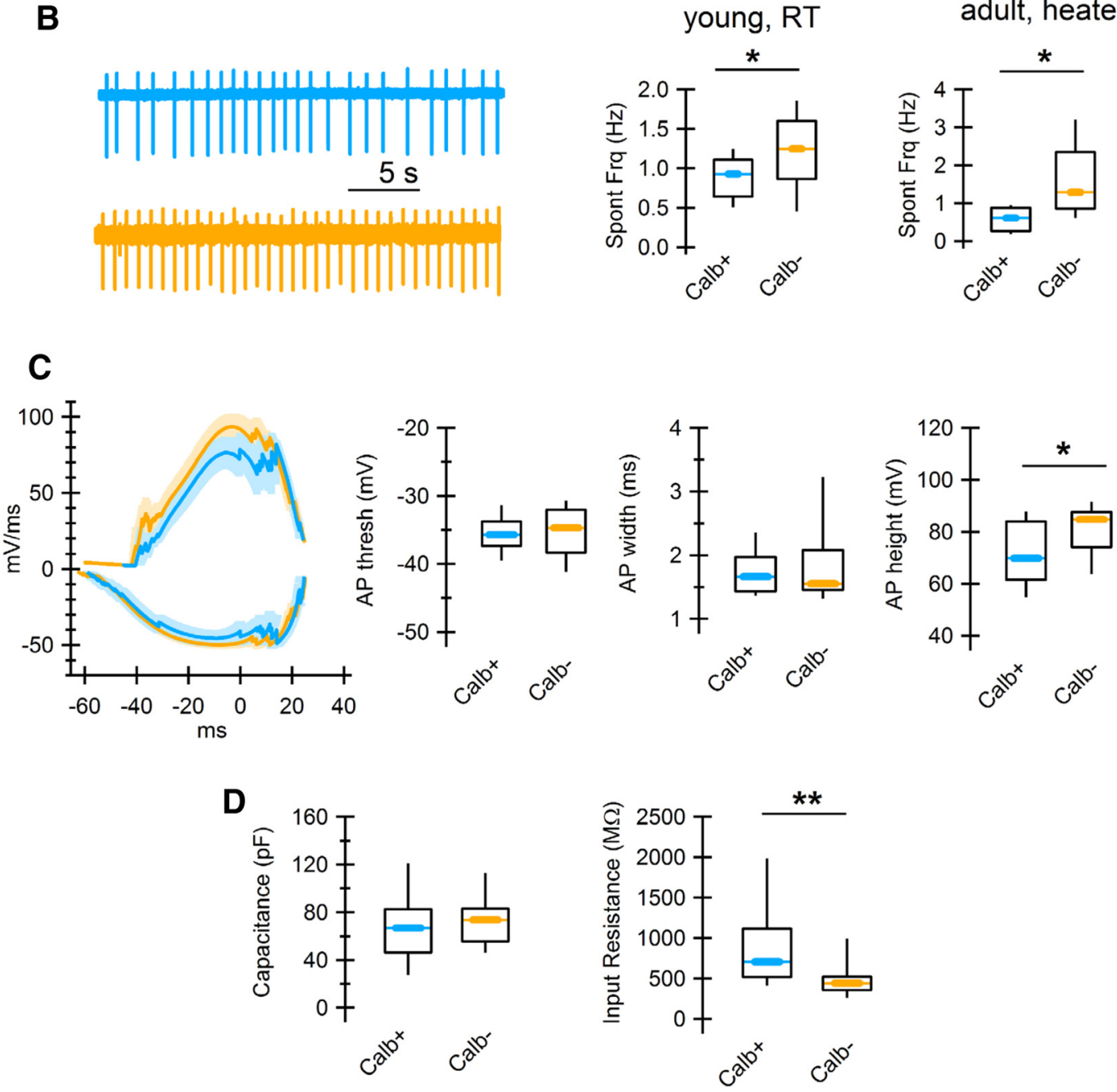

Figure 1. AP characteristics of Calb + and Calb - neurons. A, Calbindin-cre/Td-tomato mouse (red) stained for calbindin (cyan) and TH (green). B, Example cell-attached spontaneous firing recordings for a young Calb + (blue) and Calb - (yellow) cell. Thirty seconds of spontaneous firing was recorded in young Calb $-(n=12)$ and Calb $+(n=17)$ neurons at room temperature (RT; left) and in adult Calb $-(n=9)$ and Calb $+(n=4)$ heated to $30-32^{\circ} \mathrm{C}\left(\right.$ right). ${ }^{*} p=0.018$, young RT; ${ }^{*} p=0.034$, adult heated. C, Overlaid averaged phase plot of AP waveform during tonic pacemaking in adult mice heated to $30-32^{\circ} \mathrm{C}$ for Calb - (yellow) and Calb + (blue) subpopulations (left). Shading represents \pm SEM. AP activation threshold (AP thresh) and width at half-height (AP width) did not differ between subpopulations ( $n=13$ for each group). AP height differed slightly, ${ }^{*} p=0.034$. D, Capacitance and resistance measurements from adult Calb $+(n=18)$ and Calb $-(n=27)$ neurons at $30-32^{\circ} \mathrm{C} .{ }^{* *} p=0.00032$.

slice. Cells were filled with dye for $\geq 10$ min before imaging. Using EGTA-clamped $\mathrm{Ca}^{2+}$ concentrations (calculated with maxchelator; http://web.stanford.edu/ cpatton/maxc.html), we calculated the $K_{\mathrm{D}}$ of Fluo-5F as $\sim 418 \mathrm{~nm}$ at $33^{\circ} \mathrm{C}$ and $\sim 711 \mathrm{~nm}$ at room temperature. We quantified our nonlinearity $(N L)$ values for each temperature $\left[N L=d G / R_{\text {IdealVsReal }} /\right.$ $\left.\left(G / R-G / R_{\min }\right)\right]$ where $\mathrm{dG} /$ RidealVsReal is the difference between the linear approximation and the exact relationship between $\left[\mathrm{Ca}^{2+}\right]$ and $\mathrm{G} / \mathrm{R}$ signal under our experimental conditions (Yasuda et al., 2004), and found that 
G/Gs signals of $0.4,0.3$, and 0.2 resulted in nonlinearities of 44,25 , and $10 \%$ at $33^{\circ} \mathrm{C}$ and 51,30 , and $13 \%$ at room temperature $\left(22^{\circ} \mathrm{C}\right)$. These data suggest that a number of our largest $\mathrm{Ca}^{2+}$ signals were imaged under conditions of partial dye saturation and likely indicate even larger than reported increases in dendritic $\mathrm{Ca}^{2+}$ concentration (Regehr and Atluri, 1995; Maravall et al., 2000).

Immunohistochemistry and confocal imaging. In slices from TH-GFP mice, cells were filled for $\leq 6 \mathrm{~min}$ to prevent calbindin and aldehyde dehydrogenase 1 family, member A1 (Aldhla1) washout (Müller et al., 2005), after which the pipette was carefully removed. Slices were then fixed in $4 \% \mathrm{PFA}$ in PBS overnight at $4^{\circ} \mathrm{C}$. Then slices were washed $1 \times 10$ $\mathrm{min}$ in PBS, then $1 \times 10 \mathrm{~min}$ in PBS containing $0.1 \%$ Triton-X (PBST). Slices were permeabilized in PBST containing 10\% normal donkey serum for $90 \mathrm{~min}$ at room temperature and then incubated in primary antibody in PBST overnight on shaker at room temperature. After $6 \times 10$ min washes in PBST, slices were incubated in secondary antibody for $3 \mathrm{~h}$ on shaker at room temperature. After $6 \times 10$ min washes in PBS, slices were mounted with Vectashield in square frame seals (Bio-Rad) on glass slides and coverslipped. Primary antibodies were used at the following concentrations: rabbit anti-calbindin (Swant), 1:1000; sheep anti-TH (Novus Biologicals), 1:1000; rabbit anti-Aldhlal (Abcam), 1:400. Secondary antibodies were used at the following concentrations: donkey anti-rabbit Cy5 (Jackson ImmunoResearch), 1:50; donkey anti-sheep Alexa488 (Invitrogen), 1:1000. Images were acquired through $20 \times$ and $10 \times$ objectives on a spinning-disk confocal microscope.

Drugs. All salts were from Sigma-Aldrich. Fluo5F and Alexa594 (Life Technologies), gabazine, D-AP5, dopamine, and D-serine were dissolved in deionized water. TTA-P2 (Alomone), ML-218 (Tocris Bioscience), sulpiride, quinpirole, picrotoxin, nifedipine, CGP55845 (Tocris), NBQX, and cyclopiazonic acid (CPA) were dissolved in DMSO.

Analysis. Analysis was conducted in Igor (Wavemetrics). Mann-Whitney $U$ tests were used to compare two samples. Wilcoxon signed-rank tests were used for paired comparisons. For multiple comparisons, Kruskal-Wallis tests determined significance of the dataset and post hoc Mann-Whitney $U$ tests determined significance between groups. Data in text is reported as mean \pm SEM and error bars on graphs are indicated as \pm SEM. Box plots show medians, 25 and $75 \%$ (boxes) percentiles, and 10 and $90 \%$ (whiskers) percentiles.

\section{Results}

Low-threshold $\mathrm{Ca}^{2+}$ depolarizations occur in $\mathrm{Calb}-$, but not Calb,+ SNc neurons

Substantia nigra dopamine neurons fire spontaneously at characteristically low rates ( $<5$ spikes/s) in in vivo experiments and in brain slices. Previous in vivo (Brown et al., 2009) and in vitro studies (Neuhoff et al. 2002) showed that Calb- SNc dopamine neurons fire tonically at slightly higher rates than Calb $+\mathrm{SNc}$ neurons. Therefore, we compared spontaneous activity in Calb + and Calb- SNc neurons from a calbindin-cre mouse line (Zeng, 2013) crossed with the Ai9 td-tomato line [Calb1-2A-dgCre-D/ $A i 9(R C L-t d T)$; Fig. 1A]. In sagittal brain slices, cell-attached recordings of spontaneous firing in SNc neurons showed that Calb - neurons fire at slightly higher rates in juvenile $(\mathrm{Calb}+$, $0.87 \pm 0.07 \mathrm{~Hz}, n=17$ cells from 11 mice; Calb,$- 1.23 \pm 0.13 \mathrm{~Hz}$, $n=12$ cells from 11 mice, $p=0.018$ ) and adult mice (Calb+, $0.59 \pm 0.16 \mathrm{~Hz}, n=4$ cells from 4 mice; Calb,$- 1.6 \pm 0.29 \mathrm{~Hz}$, $n=9$ cells from 6 mice, $p=0.034$; Fig. $1 B$ ). Whole-cell recordings of APs during pacemaking showed that threshold, width, and height were similar between these two subpopulations (Fig. $1 C, D)$. These results show that $\mathrm{SNc}$ neuron subpopulations are relatively uniform in their tonic firing properties.

Upon hyperpolarization, however, striking differences between Calb + and Calb - neurons were apparent. To test the effect of hyperpolarization on excitability of Calb + and Calb - neurons, we evoked a $20 \mathrm{~Hz}$ AP triplet after holding over a range of hyperpolarized membrane potentials for $900 \mathrm{~ms}$. Surprisingly, we found that a large afterdepolarization developed at hyperpolarized potentials in the Calb-, but not Calb+, neurons (Fig. 2B, top). Two-photon $\mathrm{Ca}^{2+}$ imaging revealed a simultaneous dramatic increase in dendritic $\mathrm{Ca}^{2+}$ (Fig. $2 B$, bottom). When plotted against the baseline membrane voltage, the area under the curve (AUC) of the triplet-evoked depolarization and the dendritic $\mathrm{Ca}^{2+}$ amplitude increase steeply with hyperpolarization in the Calb-, but not the Calb+, neuron (Fig. 2C).

On average, the AUC of depolarizations measured from -80 $\mathrm{mV}$ was larger in Calb - neurons $\left(4.8 \pm 0.63 \mathrm{mV}^{\star} \mathrm{s}, n=10\right.$ cells from 8 mice) than Calb + neurons $\left(2.24 \pm 0.27 \mathrm{mV}^{\star} \mathrm{s}, n=26\right.$ cells from 11 mice; Mann-Whitney $U$ test, $p=0.0067)$. Likewise, simultaneously imaged dendritic $\mathrm{Ca}^{2+}$ signals were considerably larger in Calb- neurons $(0.3 \pm 0.051 d G / G s)$ than in Calb + neurons $(0.063 \pm 0.016 \mathrm{dG} / \mathrm{Gs}$; Mann-Whitney $U$ test, $p=$ 0.0024 ; Fig. $2 D$, top). We observed a similar pattern in adult mice $\left(30-32^{\circ} \mathrm{C}\right)$ where the AUC of depolarizations evoked by singlecurrent injections was significantly larger in Calb- neurons (1.6 $\pm 0.18 \mathrm{mV}^{\star} \mathrm{s}, n=27$ cells from 14 mice) than in Calb + neurons $\left(0.48 \pm 0.08 \mathrm{mV}^{\star} \mathrm{s}, n=18\right.$ cells from 11 mice, MannWhitney $U$ test, $p=0.000023)$, and the $\mathrm{Ca}^{2+}$ amplitude was larger in Calb - neurons $(0.15 \pm 0.024 d G / G s)$, than in Calb + neurons $(0.046 \pm 0.014 d G / G s$; Mann-Whitney $U$ test, $p=$ 0.00019; Fig. 2D, bottom).

In Figure $2 E$, we plotted dendritic $\mathrm{Ca}^{2+}$ signals against the AUC for individual cells measured from baseline voltages closest to $-80 \mathrm{mV}$. In a set of separately recorded unlabeled wild-type neurons (Fig. 2E, open symbols), we found a strong correlation between the size of the low-threshold depolarization (AUC) and the dendritic $\mathrm{Ca}^{2+}$ signal [Pearson's $\mathrm{R}$ value $(\mathrm{Pr})=0.71, n=128$, $p=0.00001]$. Unlabeled wild-type neurons and the Calb- neurons cover a range of values, while Calb + neurons are clustered and more likely to exhibit low AUC and low $\mathrm{Ca}^{2+}$ amplitudes (Fig. 2E). Consistent with Neuhoff et al. (2002), our findings indicate that the $\mathrm{Calb}+$ neurons of the dorsal tier are a physiologically distinct subpopulation of the SNc dopamine neurons.

\section{Aldh1a1-positive SNc dopamine neurons display low-threshold depolarizations}

Recently, Aldhlal has been shown to be critical for GABA corelease from dopamine neurons (Kim et al., 2015), and was identified as a potential marker for vulnerable SNc dopamine neurons (Liu et al., 2014; Poulin et al., 2014). Additionally, molecular profiling studies show that Aldh1a1-positive SNc neurons are located in the ventral tier and are mostly Calb- (Anderegg et al., 2015; Poulin et al., 2014), suggesting that the Aldh1a1+ and Calb-SNc neurons may share similar physiological characteristics. To compare Aldh1a1+, Calb+, and Calb- subpopulations under matched experimental conditions, we recorded dopamine neurons from TH-GFP mice and tested for Calb1 or Aldh1a1 expression with post hoc immunostaining (Fig. $3 A, B$ ). In preliminary experiments, we observed a time-dependent washout of calbindin during whole-cell recordings similar to reports in hippocampal neurons of the dentate gyrus (Müller et al., 2005). Therefore, to minimize washout and enable post hoc identification, recordings were limited to $\leq 6 \mathrm{~min}$.

Comparing low-threshold depolarizations between these three cell populations, we found a significant effect of immunostaining category (Calb-, Calb + , Aldhla1 + ; Kruskal-Wallis test, $H=$ 11.42, $p=0.0026)$. Similar to results from Calb1-Cre mice, Calb - neurons identified with immunostaining showed prominent low-threshold depolarizations (AUC, $4.6 \pm 0.3 \mathrm{mV}^{\star} \mathrm{s}, n=$ 22 cells from 5 mice) while the Calb + neurons did not (AUC, 


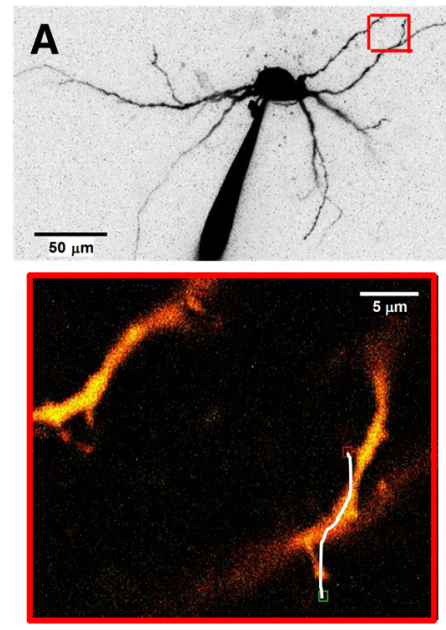

D

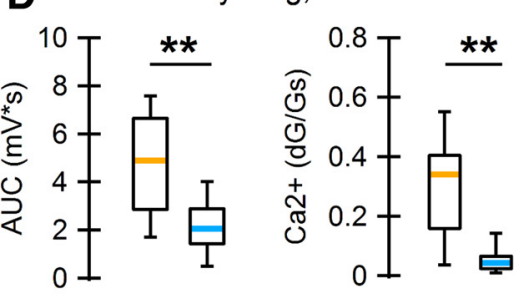

adult, heated
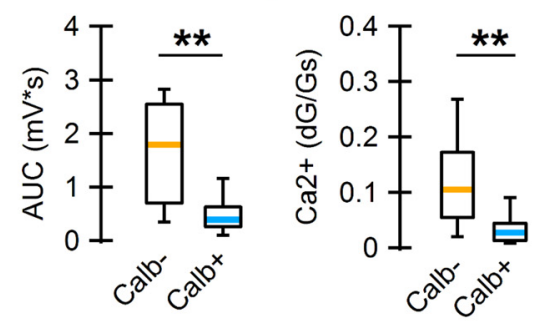

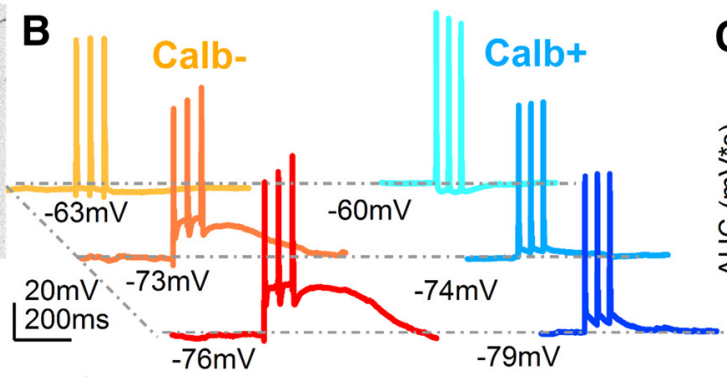

C
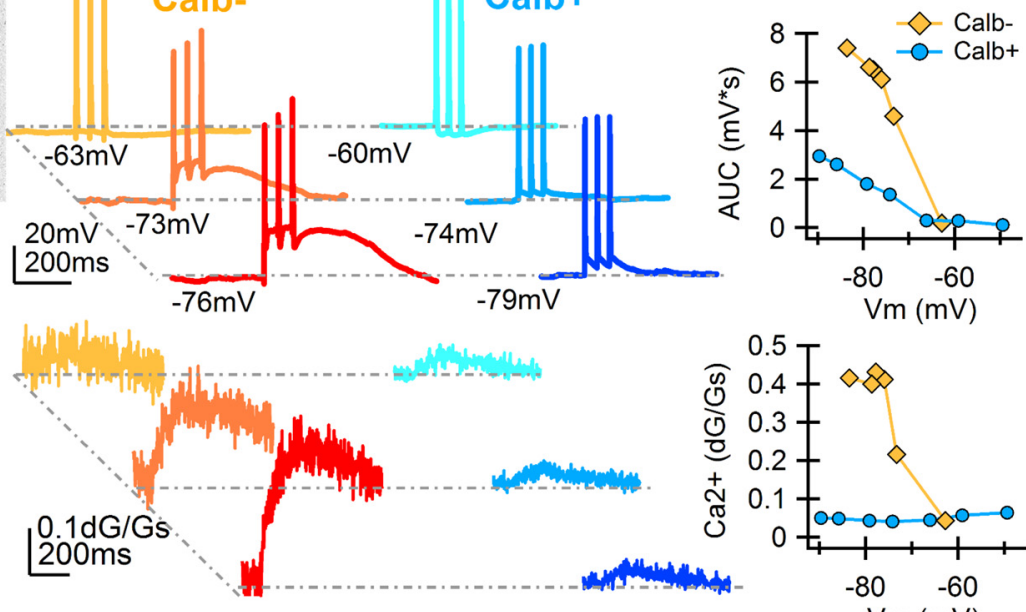

E

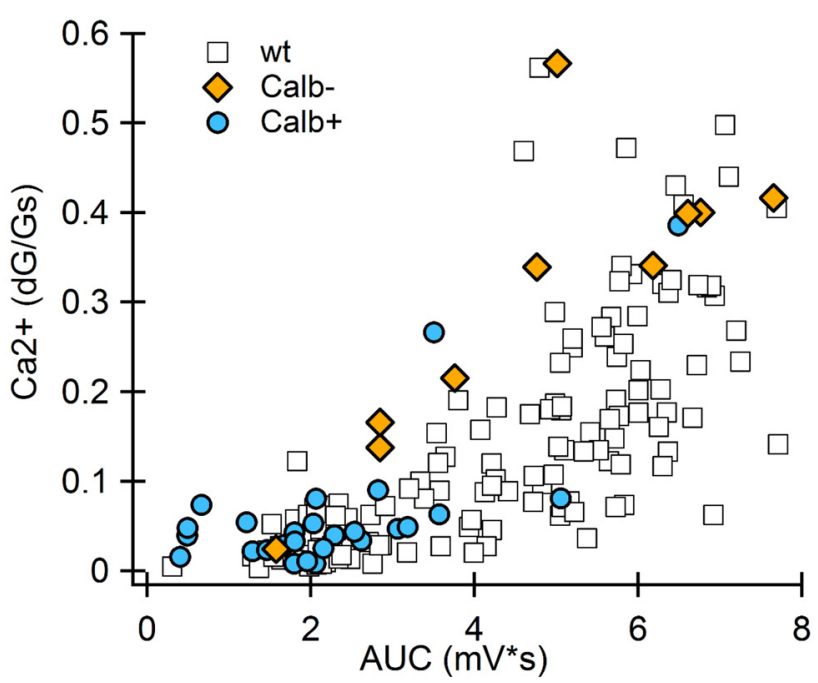

Figure 2. Hyperpolarization reveals differences between Calb + and Calb $-S N c$ neurons. $A$, Two-photon image SNc dopamine neuron with patch pipette. Inset, Higher-magnification image of region in red box. Scan path through a spine and dendrite indicated by white line. $\boldsymbol{B}$, Low-threshold afterdepolarizations in response to a $20 \mathrm{~Hz}$ AP triplet occurs with hyperpolarization in Calbneurons (left traces), but not Calb + neurons (right traces). Differences are reflected in membrane potential (above) and dendritic calcium ( $\left(\mathrm{Ca}^{2+}\right.$ ) amplitudes (below) in young mice. $C$, AUC (above) and $\mathrm{Ca}^{2+}$ (below) amplitude plotted by baseline $V_{\mathrm{m}}$ for the example neurons. $D$, Comparison between Calb - and Calb $+\mathrm{AUC}$ and $\mathrm{Ca}^{2+}$ amplitude from membrane potential closest to $-80 \mathrm{mV}$ in each cell in neurons from young (Calb $-n=10$; Calb $+n=27$ ) and adult (Calb $-n=26$, Calb $+n=18$ ) mice. ${ }^{* *} p<0.001 . E$, Ca ${ }^{2+}$ amplitude plotted by AUC measured at membrane potential closest to $-80 \mathrm{mV}$ for Calb + and Calb - cells. Unlabeled neurons from wild-type mice (wt; open squares) span a wide range of values, demonstrating heterogeneity in unlabeled SNc neurons.

$2.7 \pm 0.39 \mathrm{mV}^{\star} \mathrm{s}, n=13$ cells from 6 mice; Mann-Whitney $U$ test $p=0.0024)$. Interestingly, we found that Aldh1a1+ neurons also displayed low-threshold depolarizations (AUC, $4.5 \pm 0.3 \mathrm{mV}^{*} \mathrm{~s}$, $n=10$ cells from 3 mice) that were significantly larger than those of the Calb + neurons (AUC, $2.7 \pm 0.39 \mathrm{mV}^{\star} \mathrm{s}, n=13$ cells from 6 mice; Mann-Whitney $U$ test, $p=0.0015)$, but indistinguishable from those measured in Calb - neurons (AUC, $4.6 \pm 0.3 \mathrm{mV}^{\star} \mathrm{s}$, $n=22$ cells from 5 mice; Mann-Whitney $U$ test, $p=0.7$; Fig. $3 C-E)$.

SNc dopamine neurons are characterized by a depolarizing voltage sag that is most prominent in Calb-SNc neurons. This indicates a higher density $I_{\mathrm{h}}$ (Neuhoff et al., 2002). We found that the voltage sags in Aldhlal+ neurons $(17.9 \pm 2.0 \mathrm{mV}, n=10$ cells from 3 mice; Mann-Whitney $U$ test, $p=5.7 \mathrm{e}-5)$ and Calbneurons $(18.5 \pm 0.11 \mathrm{mV}, n=31$ cells from 13 mice; MannWhitney $U$ test, $p=4.9 \mathrm{e}-11)$ were significantly larger than in Calb + neurons $(7.1 \pm 0.07 \mathrm{mV}, n=34$ cells from 17 mice $)$. Sag amplitude data collected from neurons stained post hoc did not differ from those collected from the calbindin-cre mice, and were therefore pooled (Fig. $3 F, G$ ). Our comparison of low-threshold depolarizations and sag potentials demonstrate that Aldh1a1+ SNc neurons share similar characteristics with the Calb- SNc neurons. Therefore, our functional data supports results from genetic sequencing studies (Poulin et al., 2014) that indicate that Aldh1a1+ and Calb - SNc neuron subpopulations may partially overlap.

Hyperpolarization increases sensitivity to synaptic frequency To test whether low-threshold depolarizations could be activated synaptically, we recorded cells in the presence of picrotoxin (50 $\mu \mathrm{M})$ or gabazine $(10 \mu \mathrm{M})$ to isolate excitatory inputs. Excitatory synaptic stimulation evoked low-threshold depolarizations, which could be eliminated by blocking NMDA and AMPA receptors (data not shown). To test the relative effect of synaptic input frequency at hyperpolarized and depolarized potentials, we delivered four synaptic stimuli over a range of frequencies $(28-200$ 

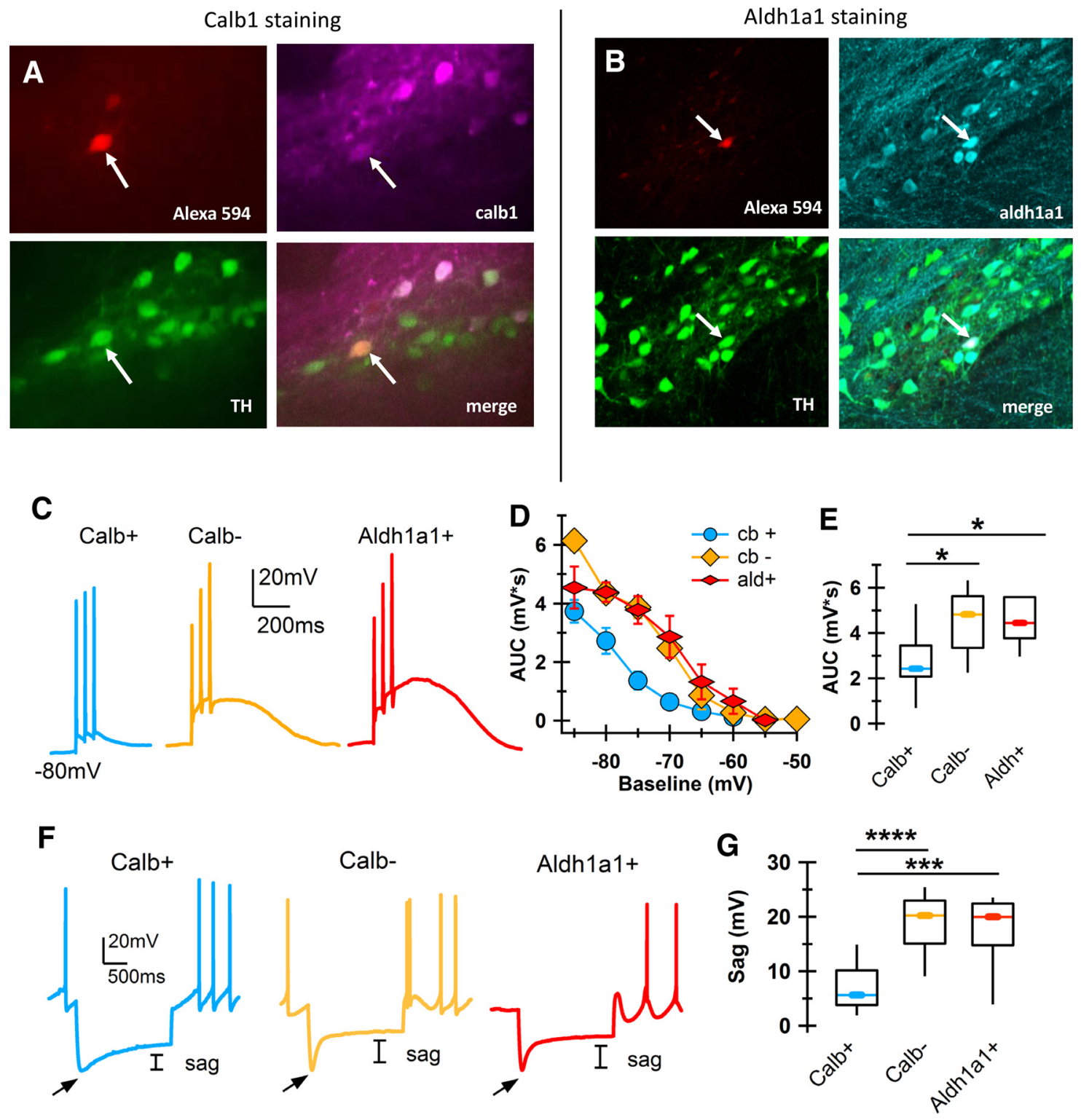

Figure 3. Calb - and Aldh1a1+SNc dopaminergic neurons display similar characteristics. A, Sagittal section of the substantia nigra. Genetically labeled TH-positive dopamine neurons (green neurons) were filled with Alexa594 (red) and stained for calbindin (magenta). B, Sagittal section of the substantia nigra immunostained for aldehyde dehydrogenase (cyan). $\boldsymbol{C}$, Example traces of low-threshold depolarization in TH-positive neurons that were identified as Calb + (blue), Calb - (yellow), and Aldh1a1+ (red) using post hoc immunostaining. D, AUC as a function of membrane potential in post hoc stained neurons. cb+, Calb + neurons; cb-, Calb- neurons; ald +, Aldh1a1+ neurons. $\boldsymbol{E}$, AUC measured from membrane voltage closest to - $80 \mathrm{mV}$ for each cell in Calb +, Calb-, and Aldh1a1+ neurons. ${ }^{*} p<0.01$. $\boldsymbol{F}$, Example traces from Calb + , Calb-, and Aldh1a1+ neurons showing voltage sag measurement. Black arrow indicates minimum $V_{\mathrm{m}}$. $\mathbf{G}$, Both Aldh1a1 $+(n=10)$ and Calb $-(n=31)$ neurons have significantly larger voltage sags than Calb $+(n=34)$ neurons when measured from the minimum $V_{\mathrm{m}}$ closest to $-100 \mathrm{mV}$ for each cell. ${ }^{* * *} p<0.0001^{* * * *} p<1 \mathrm{e}-9$.

$\mathrm{Hz}$ ) using a theta-glass stimulating electrode. For each cell, the location of the stimulating electrode and the stimulation strength were the same at hyperpolarized and depolarized potentials and for all stimulation frequencies. To ensure accurate comparisons and prevent spontaneous firing, we applied holding current and adjusted the strength of the stimulus to below AP threshold levels. Simultaneously, $\mathrm{Ca}^{2+}$ was imaged in dendritic segments at an average distance of $42 \pm 12 \mu \mathrm{m}$ from the site of stimulation. Figure $4 A$ shows one cell's response to synaptic stimulation when held first at a depolarized potential $(-58 \mathrm{mV}$; green traces) and then at a hyperpolarized potential $(-70 \mathrm{mV}$; black traces $)$. At depolarized potentials, we observed a slight subthreshold depolarization, likely due to NMDA receptor activation. However, at hyperpolarized potentials, where NMDA receptors are more strongly blocked by $\mathrm{Mg}^{2+}$, low-threshold depolarizations were observed only in response to high stimulation frequencies. In recordings from five wild-type neurons, which displayed lowthreshold depolarizations, the frequency required for a lowthreshold depolarization ranged from 40 to $66 \mathrm{~Hz}$. Averaging these neurons, we found that hyperpolarization enables a nonlinear dependence on input frequency. The size of the response to $66 \mathrm{~Hz}$ synaptic stimulation at depolarized potentials (average baseline $V_{\mathrm{m}}=-63 \pm 3 \mathrm{mV}$; average AUC, $1.2 \pm 0.4$ $\mathrm{mV}^{\star} \mathrm{s}$ ) was significantly smaller than at hyperpolarized potentials (average baseline $V_{\mathrm{m}}=-77 \pm 2.7 \mathrm{mV}$; average AUC, $3.0 \pm 0.2 \mathrm{mV}^{\star} \mathrm{s}, n=5$ cells from 5 mice, Mann-Whitney $U$ test, $p=0.008$ ), as was the dendritic $\mathrm{Ca}^{2+}$ signal (average $d G / G s$, depolarized, $0.019 \pm 0.005 d G / G s$; hyperpolarized, 

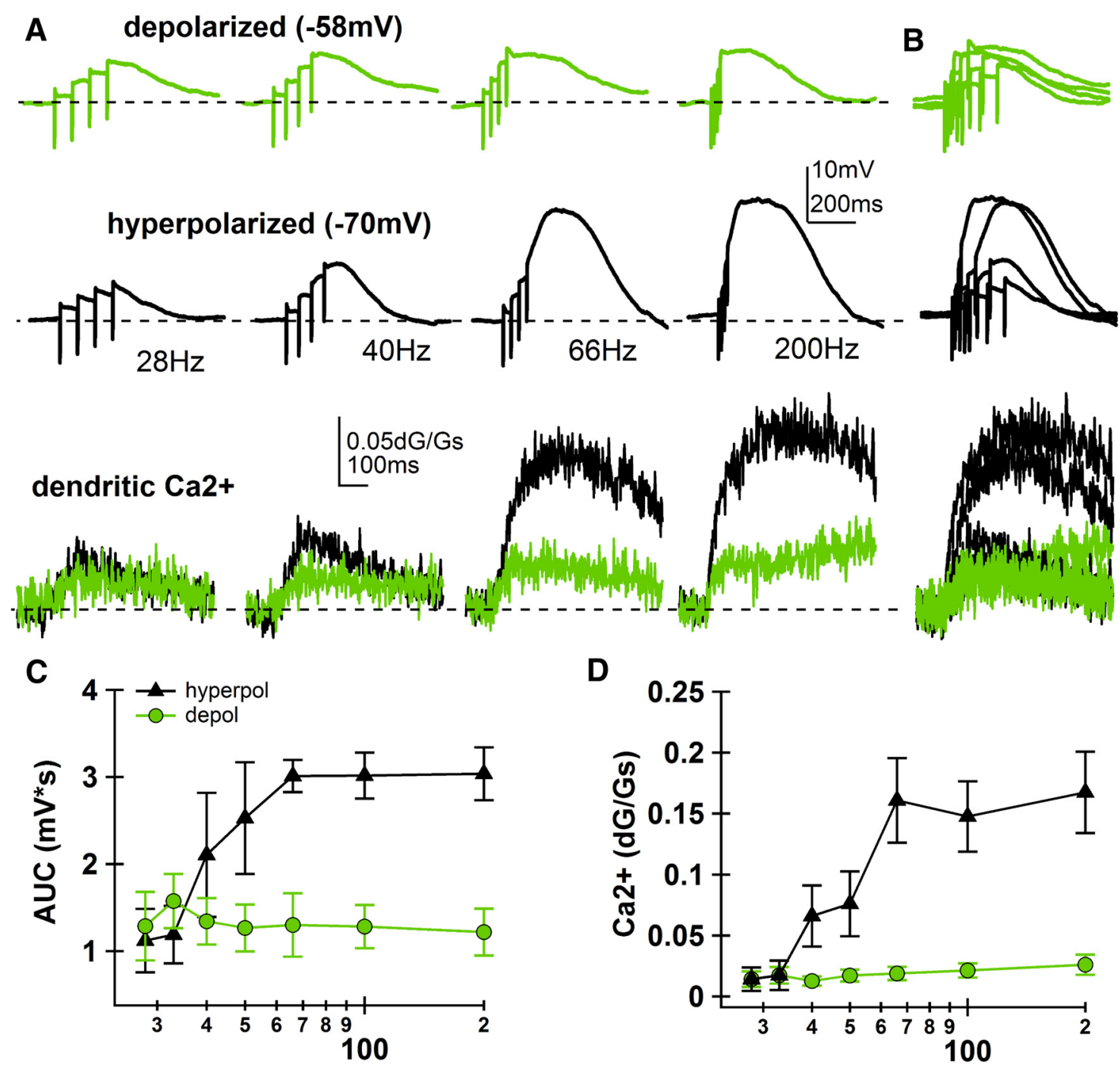

Log Frequency $(\mathrm{Hz})$

D

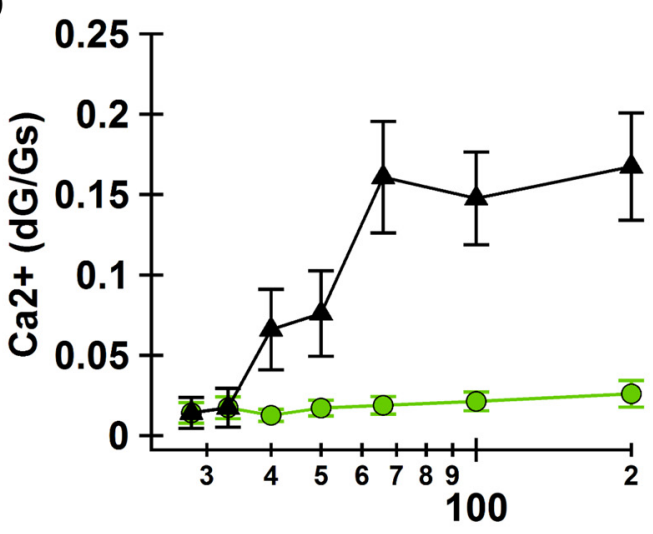

Log Frequency $(\mathrm{Hz})$

Figure 4. Synaptically generated low-threshold depolarizations depend on input frequency. $A$, Example traces from an $S N$ c neuron given four excitatory synaptic stimulation pulses at different frequencies from depolarized (top) and hyperpolarized (middle) potentials. Bottom, Corresponding calcium traces. $\boldsymbol{B}$, Overlay of responses for all frequencies in $\boldsymbol{A}$. $\boldsymbol{C}$, Size of low-threshold depolarizations (AUC) versus stimulation frequency. Note, AUC increases nonlinearly with input frequency at hyperpolarized (black) but not depolarized (green) potentials. D, Same as C, but for Ca ${ }^{2+}$ amplitude. Data are presented as mean \pm SEM.

$0.16 \pm 0.03 d G / G s ;$ Mann-Whitney $U$ test, $p=0.008)$. These results show that the effect of hyperpolarization on dopamine neurons is to increase temporal summation of synaptic input, demonstrating that integration of synaptic input is substantially different at hyperpolarized potentials than at depolarized potentials.

T-type $\mathrm{Ca}^{2+}$ channels are necessary for synaptically driven and current injection-evoked low-threshold depolarizations We have shown that the Calb - and Calb + neurons of the SNc display striking differences when activated from hyperpolarized potentials. The particular characteristics of the low-threshold depolarization, such as the requirement for hyperpolarization and the accompanying large dendritic $\mathrm{Ca}^{2+}$ transient, are consistent with events generated by T-type $\mathrm{Ca}^{2+}$ channels, as has been observed in the thalamus (Jahnsen and Llinás, 1984; Connelly et al., 2015) and cerebellum (Aizenman and Linden, 1999). In dopamine neurons, early studies reported that a subset of neurons could generate low-threshold spikes (Llinás et al., 1984; Kang and
Kitai, 1993a), and the presence T-type $\mathrm{Ca}^{2+}$ channels in dopamine neurons has been confirmed through staining (Dufour et al., 2014) and voltage-clamp recordings (Kang and Kitai, 1993b; Poetschke et al., 2015; Philippart et al., 2016).

To test whether T-type $\mathrm{Ca}^{2+}$ channels were necessary for the low-threshold depolarization, TTA-P2 $(1 \mu \mathrm{M})$, a selective T-type channel blocker (Shipe et al., 2008; Dreyfus et al., 2010), was bath-applied to wild-type cells, which displayed low-threshold depolarizations, while low-threshold depolarizations were synaptically generated once every $20 \mathrm{~s}$. In young wild-type mice, stimulation was delivered (four pulses, $100 \mathrm{~Hz}$ ) to generate a low-threshold depolarization from a hyperpolarized holding potential. When measured 6-8 min after TTA-P2 application, the size of the synaptically evoked low-threshold depolarization was greatly reduced [control, $95.8 \pm 6.6 \%, n=8$ (five cells, four young mice; three cells, two adult mice); TTA-P2, $48.4 \pm 7.9 \%, n=5$ cells from five mice; MannWhitney $U$ test, $p=0.0062$ ] as was the corresponding dendritic $\mathrm{Ca}^{2+}$ signal (control, $75.9 \pm 9.1 \%$; TTA-P2, $13.1 \pm 2.2 \%$; MannWhitney $U$ test, $p=0.0016$; Fig. $5 A$ ). 
A

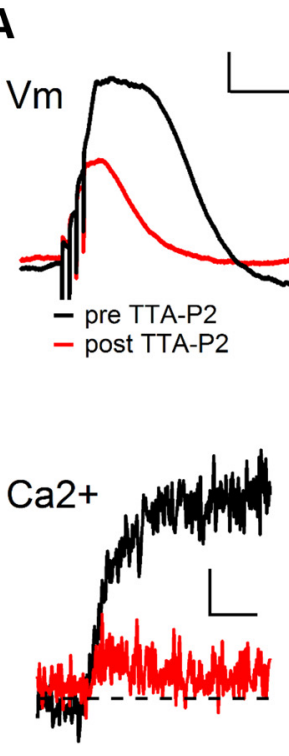

B

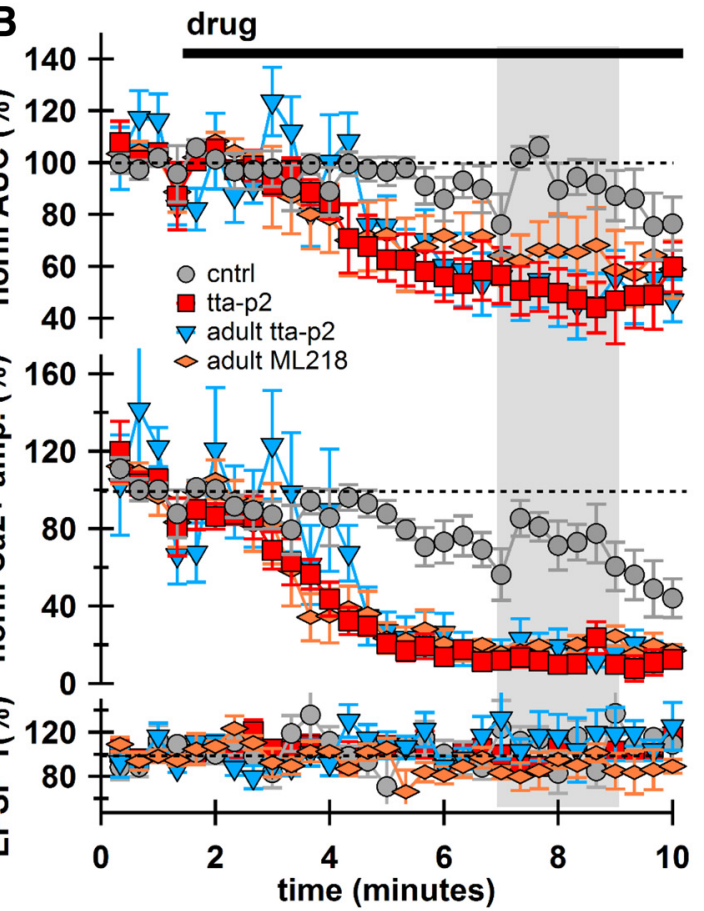

D

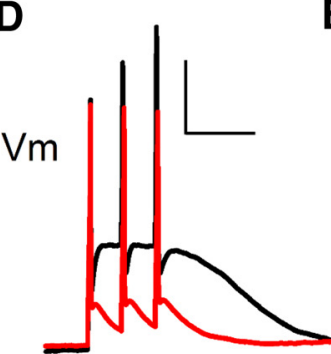

- pre TTA-P2

- post TTA-P2

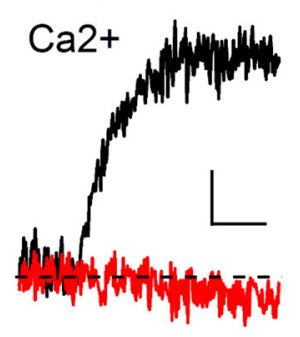

E
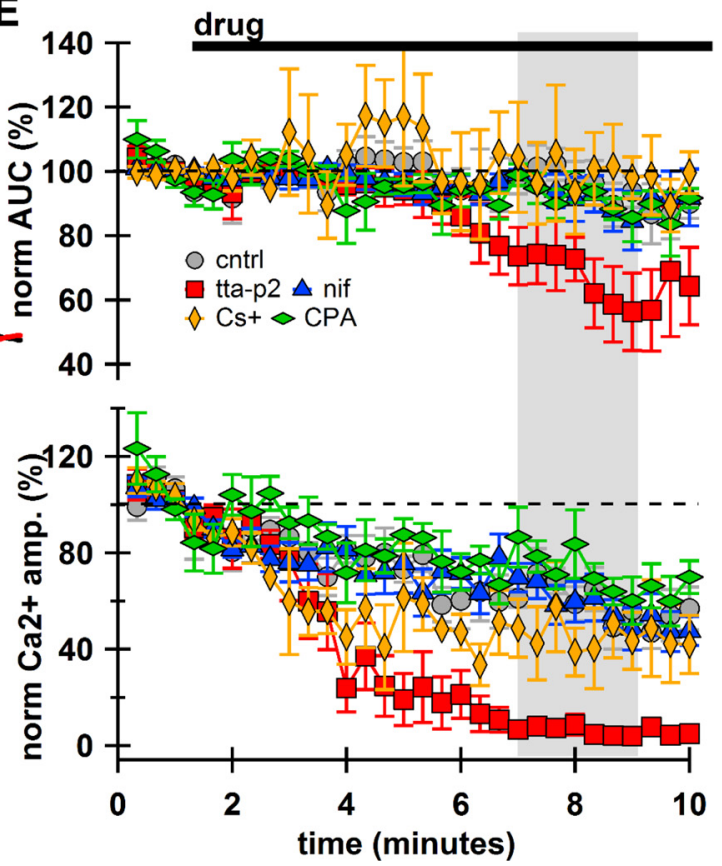
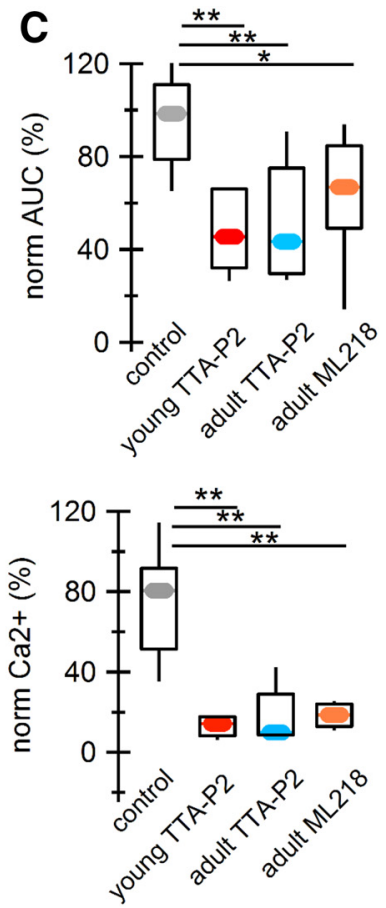

$\mathbf{F}$

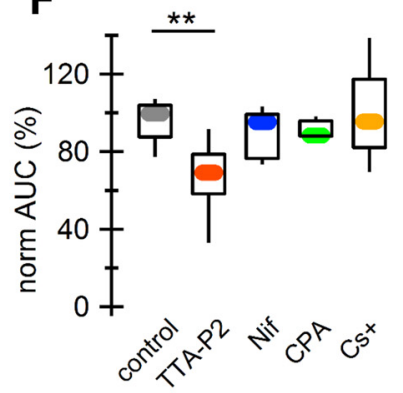

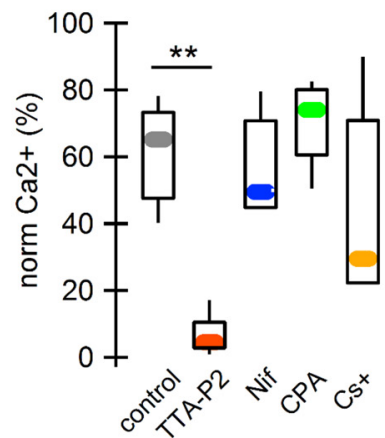

Figure 5. T-type $\mathrm{Ca}^{2+}$ channels are necessary for low-threshold depolarizations. $A$, Example traces showing synaptically evoked low-threshold depolarizations (top; 5 cale bars: $5 \mathrm{mV}$, $100 \mathrm{~ms}$ ) and dendritic $\mathrm{Ca}^{2+}$ signals (bottom; scale bars: $0.025 \mathrm{dG} / \mathrm{Gs}, 100 \mathrm{~ms}$ ) before (black) and after (red) TTA-P2 application. B, Time course for drug application on AUC, $\mathrm{Ca}^{2+}{ }^{2}$, and first EPSP amplitude compared with no-drug control ( $n=8,5$ young, 3 adult). C, Summarized data from shaded area in $\boldsymbol{B} .{ }^{* *} p<0.01{ }^{*} p<0.05$. D, Example low-threshold depolarization (top; scale bars: $20 \mathrm{mV}$, 100 $\mathrm{ms}$ ) and dendritic $\mathrm{Ca}^{2+}$ signal (bottom; scale bars: $0.05 \mathrm{dG} / \mathrm{Gs}, 100 \mathrm{~ms}$ ) before drug application (black) and after TTA-P2 application (red) in young mice. $\boldsymbol{E}$, Time course for drug effect on low-threshold depolarization (AUC, top) and dendritic $\mathrm{Ca}^{2+}{ }^{2}$ signal (bottom), compared with no-drug control. cntrl, Control; nif, Nifedipine; CPA, Cyclopiazonic acid; Cs +, Cesium. F, Summarized data from shaded area in $E$. ${ }^{* *} p<0.01^{*} p<0.05$.

Because immunostaining studies suggest that T-type channel expression may change during development (Dufour et al., 2014), we repeated this experiment in adult TH-GFP mice. Stimulations for each cell were tuned to generate a low-threshold depolarization from hyperpolarized potentials (10-200 ms, 100$350 \mathrm{~Hz}$ ). No-drug control experiments measured at 6-8 min did not differ between young ( $n=5$ cells from 4 mice) and adult $(n=$ 3 cells from 2 mice) mice, and were therefore pooled. In adult mice, TTA-P2 greatly reduced the dendritic $\mathrm{Ca}^{2+}$ signal $(16.9 \pm$ $6.5 \%, n=5$ cells from 4 mice; Mann-Whitney $U$ test vs control, $p=0.0031)$ and the AUC ( $50.5 \pm 11.5 \%$; Mann-Whitney $U$ test vs control, $p=0.0062$ ). A separate selective inhibitor of T-type channels, ML218 (Xiang et al., 2011), also reduced the dendritic $\mathrm{Ca}^{2+}$ signal $(18.3 \pm 2.3 \%, n=6$ cells from 5 mice; Mann-Whitney $U$ test vs control, $p=0.00067)$ and the AUC $(64.0 \pm 11.1 \%$; Mann-Whitney $U$ test vs control, $p=0.020)$. Before these post 

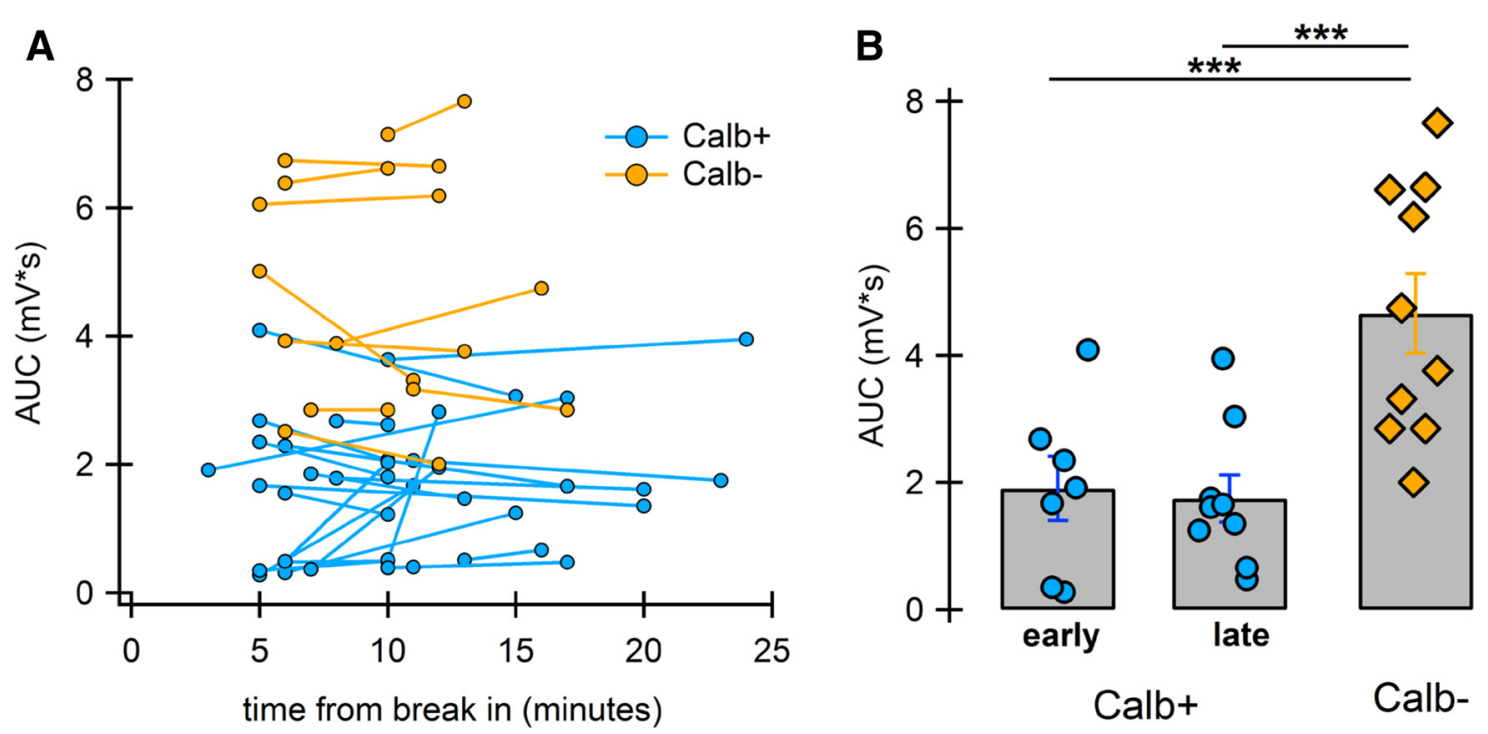

Figure 6. Calbindin washout does not affect low-threshold depolarization. $A$, AUC in response to $20 \mathrm{~Hz}$ triplet measured in young mice at membrane voltage closest to - $80 \mathrm{mV}$ at two different time points measured from the time whole-cell configuration was achieved (break in). Time from break in did not alter the AUC for either Calb -0 or Calb + neurons. $B$, AUC from Calb + neurons measured early ( $<5 \mathrm{~min}$ from break in) and late ( $>15 \mathrm{~min}$ from break in) differ from Calb - (average time from break in, $12.6 \pm 0.7 \mathrm{~min}$ ). ${ }^{*} p<0.01$. Bar graph shows mean $\pm \mathrm{SEM}$.

hoc comparisons, a Kruskal-Wallis test was run on all drug conditions and showed that drug application had a significant effect on AUC (Kruskal-Wallis test, $p=0.0039$ ) and dendritic $\mathrm{Ca}^{2+}$ (Kruskal-Wallis test, $p=0.00013$; Fig. $5 B, C$ ). Importantly, neither TTA-P2 nor ML218 altered the amplitude of the first EPSP in adult or young mice (Kruskal-Wallis test, $p=0.66$ ), indicating that T-type $\mathrm{Ca}^{2+}$ channels have little influence on presynaptic vesicle release at excitatory synapses onto SNc neurons (Fig. 5B).

To examine possible contributions of other channels, we conducted a battery of pharmacological tests on triplet-evoked low-threshold depolarizations. As before, TTA-P2 reduced the dendritic $\mathrm{Ca}^{2+}$ signal (control, $61.4 \pm 6.5 \%, n=5$; TTA-P2, $6.5 \pm 2.3 \%, n=6$; Mann-Whitney $U$ test, $p=0.004)$ and AUC (control, $96.5 \pm 5.1 \%$; TTA-P2, $67.3 \pm 7.8 \%$; Mann-Whitney $U$ test, $p=0.009$; Fig. $5 D$ ). Because $I_{\mathrm{h}}$ is stronger in Calb - neurons than in Calb + neurons (Neuhoff et al., 2002), we tested whether cesium (Cs + ), a blocker of $I_{\mathrm{h}}$, would reduce the low-threshold depolarization. Cs+ (2 mm) had no significant effect on the lowthreshold depolarization (control, $96.5 \pm 5.1 \%, n=5$ cells from 5 mice; Cs $+, 98.8 \pm 11.1 \%, n=5$ cells from 4 mice; MannWhitney $U$ test, $p=0.42$ ) or the $\mathrm{Ca}^{2+}$ transient (control, $61.4 \pm 6.5 \%$; Cs+, $43.1 \pm 12.9 \%$; Mann-Whitney $U$ test, $p=0.22$; Fig. $5 E$ ).

$\mathrm{SNc}$ neurons express a high density of L-type $\mathrm{Ca}^{2+}$ currents, which are active during subthreshold voltages (Chan et al., 2007; Puopolo et al., 2007; Hage and Khaliq, 2015). However, a high concentration of nifedipine $(10 \mu \mathrm{M})$, sufficient to block $80 \%$ of the Cav1.3 subunit from a $-80 \mathrm{mV}$ membrane potential (Helton et al., 2005), had no significant effect on the low-threshold depolarization (control, $96.5 \pm 5.1 \%, n=5$ cells from 5 mice; nifedipine $89.3 \pm 5.5 \%, n=5$ cells from 4 mice; Mann-Whitney $U$ test, $p=0.31$ ) or on the amplitude of the dendritic $\mathrm{Ca}^{2+}$ signal (control, $61.4 \pm 6.5 \%$; nifedipine, $56.2 \pm 6.6 \%$; Mann-Whitney $U$ test, $p=0.69$ ). This result may seem surprising because SNc neurons contain low-threshold L-type channels (Cav1.3), which contribute to the $\mathrm{Ca}^{2+}$ oscillations that underlie tonic pacemaking (Chan et al., 2007; Guzman et al., 2009; Khaliq and Bean, 2010). However, the membrane potential during the lowthreshold depolarization peaks at $\sim-55 \mathrm{mV}$, where the L-type current is small and only starting to activate (see Fig. 8). Our findings agree with those of previous work reporting that the L-type controlled pacemaker oscillation is a separate phenomenon from the low-threshold depolarization (Kang and Kitai, 1993a; Wilson and Callaway, 2000). Finally, we found that depleting internal $\mathrm{Ca}^{2+}$ stores with CPA $(10 \mu \mathrm{M})$ did not affect the low-threshold depolarization (control, $96.5 \pm 5.1 \%, n=5$ cells from 5 mice; CPA, $91.2 \pm 2 \%, n=5$ cells from 3 mice; MannWhitney $U$ test, $p=0.22$ ) or the dendritic $\mathrm{Ca}^{2+}$ signal (control, $61.4 \pm 6.5 \%$; CPA, $71.1 \pm 5.5 \%$; Mann-Whitney $U$ test, $p=0.31$; Fig. $5 E, F)$. Before conducting the above post hoc tests, a KruskalWallis test run on all drug conditions determined that drug treatment had a significant effect on both AUC and $\mathrm{Ca}^{2+}$ amplitude (Kruskal-Wallis test, AUC, $H=11.1, p=0.02 ; \mathrm{Ca}^{2+}$ signal, $H=$ 15.8, $p=0.0008$; Fig. $5 E, F)$.

The defining difference between the Calb + and Calb - neurons is their expression of the calbindin molecule. Because calbindin binds to $\mathrm{Ca}^{2+}$, it may contribute to their differential ability to generate these calcium-dependent low-threshold depolarizations. To examine this possibility, we took advantage of the fact that calbindin washes out of the neuron during whole-cell recording with a time constant of $9.7 \mathrm{~min}$ (Müller et al., 2005). We analyzed the AUC for Calb + and Calb - neurons at different times relative to the time whole-cell configuration was achieved. We found no correlation between time from break in and the AUC for either Calb $-(\operatorname{Pr}=0.1, n=20, p=0.67)$ or Calb + $(P r=0.16, n=41, p=0.32)$ neurons (Fig. 6A), and there was no difference between the AUC of Calb + neurons at early time points ( $<5 \mathrm{~min}, 1.9 \pm 0.5 \mathrm{mV}^{\star} \mathrm{s}, n=7$ cells from 6 mice) compared with late time points $\left(>15 \mathrm{~min}, 1.7 \pm 0.4 \mathrm{mV}^{\star} \mathrm{s} ; n=9\right.$ cells from 6 mice; Mann-Whitney $U$ test, $p=0.68$; Fig. $6 B$ ). However, the AUC at both early and late time points in Calb+ neurons is significantly different from the AUC of Calb - neurons (average $12.6 \pm 0.7 \mathrm{~min}$ from break in, $4.7 \pm 0.6 \mathrm{mV}^{\star} \mathrm{s}, n=10$ cells from 8 mice; Mann-Whitney $U$ test vs Calb + early, $p=0.0046$; vs Calb + late, $p=0.0015$ )

These results indicate that, while calbindin may play an important physiological role in these subpopulations, the ability of Calb - neurons to generate low-threshold depolarizations is not directly due to their lack of calbindin. 


\section{T-type $\mathrm{Ca}^{2+}$ channels influence rebound spike timing}

Previous work in SNc dopamine neurons has shown that $I_{\mathrm{h}}$ and the A-type potassium $\left(I_{\mathrm{A}}\right)$ currents can control the timing of rebound APs (Amendola et al., 2012). To test whether T-type $\mathrm{Ca}^{2+}$ channels also could play a role in rebound spike timing, we injected hyperpolarizing current steps for $1 \mathrm{~s}$ and measured the time to first spike (rebound delay) upon release. Comparing TTA-P2 application to time-matched no-drug control experiments, we found that TTA-P2 significantly increased the duration of the rebound delay 6-8 $\mathrm{min}$ after application (control, $103 \pm 2.3 \% n=6$ cells from 4 mice; TTA-P2, $138 \pm 13.6 \%, n=$ 7 cells from 4 mice; Mann-Whitney $U$ test, $p=0.0023$ ), and substantially reduced the rebound dendritic $\mathrm{Ca}^{2+}$ signal (control, $86 \pm 8.9 \%$; TTA-P2, $49 \pm 7.9 \%$; Mann-Whitney $U$ test, $p=$ 0.014 ; Fig. $7 A-C$ ). To ensure that this increase in rebound delay was not due to a change in $I_{\mathrm{h}}$, the voltage sag was also monitored and was not affected by TTA-P2 (control, $92 \pm 13 \%$; TTA-P2, $99 \pm 8.2 \%$; Mann-Whitney $U$ test, $p=0.84$; Fig. $7 B$, bottom). These results show that, in addition to $I_{\mathrm{h}}$ and $I_{\mathrm{A}}$, T-type $\mathrm{Ca}^{2+}$ channels contribute significantly to rebound spike timing by shortening the delay to first spike.

Given the subpopulation differences in T-type channels, we next compared dendritic $\mathrm{Ca}^{2+}$ signals during rebound activity in $\mathrm{Calb}+$ and Calb - dopamine neurons. We released cells from a range of hyperpolarized voltages and measured rebound delays and dendritic $\mathrm{Ca}^{2+}$ signals (Fig. $7 D-F$ ). The rebound delay from strongly hyperpolarized potentials $(-75$ to $-85 \mathrm{mV}$ ) was significantly shorter in Calb - neurons $(0.23 \pm 0.1 \mathrm{~s}, n=6$ cells from 5 mice) than in Calb + neurons $(1.41 \pm 0.29 \mathrm{~s}, n=7$ cells from 5 mice; Mann-Whitney $U$ test, $p=0.0023$ ), and the rebound $\mathrm{Ca}^{2+}$ signal was significantly larger in Calb - neurons $[0.3 \pm 0.04 \mathrm{dG} /$ Gs, $n=13$ dendrites from 6 cells from 5 mice) than in Calb + neurons ( $0.07 \pm 0.01 d G / G s, n=22$ dendrites from 8 cells from 5 mice; Mann-Whitney $U$ test, $p=2.7 e-9$ ). Importantly, at more physiologically relevant levels of hyperpolarization ( -65 to -70 $\mathrm{mV}$ ), the rebound delay was significantly shorter in Calb$(0.18 \pm 0.02 \mathrm{~s}, n=4$ cells from 4 mice $)$ than in Calb + neurons $(0.83 \pm 0.23 \mathrm{~s}, n=8$ cells from 5 mice, Mann-Whitney $U$ test, $p=0.016$ ), and the rebound $\mathrm{Ca}^{2+}$ signal was still larger in Calbneurons $(0.2 \pm 0.03 d G / G s, n=12$ dendrites from 6 cells from 5 mice) than in Calb + neurons $(0.043 \pm 0.006, n=21$ dendrites from 8 cells from 5 mice; Mann-Whitney $U$ test, $p=6.8 \mathrm{e}-8$; Fig. $7 E, F)$. These results show that Calb- neurons experience large dendritic $\mathrm{Ca}^{2+}$ signals when rebounding from both strong and mild hyperpolarized potentials and more readily resume normal spiking after a pause.

In vivo studies have shown rebound spiking (Fiorillo et al., 2013) and rebound $\mathrm{Ca}^{2+}$ (Lerner et al., 2015) in subsets of SNc dopamine neurons. This rebound activation may be due to intrinsic properties, as explored above, or it may be due to a shift from synaptic inhibition to synaptic excitation. To test the effectiveness of synaptic stimulation in driving rebound bursts, we used a theta-glass electrode to locally stimulate excitatory synapses $(100 \mathrm{~Hz}, 250 \mathrm{~ms}, 0.5 \mathrm{~ms}$ pulse width) as the cell was released from hyperpolarization (Fig. $7 H$ ). Recordings were conducted in the presence of gabazine, CGP, sulpiride, and D-serine. Stimulation intensity was adjusted to generate a burst (3-10 spikes) during spontaneous firing and was the same strength at all hyperpolarization voltages (Fig. 7G). The number of spikes during the rebound ( $500 \mathrm{~ms}$ after release of current) was significantly attenuated by hyperpolarization in Calb + neurons [depolarized, -50 to $-60 \mathrm{mV}, 4.3 \pm 0.72$ spikes; hyperpolarized, -70 to $-85 \mathrm{mV}$, $0.74 \pm 0.36$ spikes; Wilcoxon signed rank test, $n=8$ cells (from 5 mice) paired, $p=0.0078$ ], but not in Calb - neurons [depolarized, $3.9 \pm 0.45$ spikes; hyperpolarized, $3.4 \pm 0.8$ spikes; Wilcoxon signed rank test, $n=6$ cells (from 5 mice) paired, $p=0.69$; Fig. 7I]. These results support a role for T-type currents in the maintenance of excitability during inhibition as has been observed in the thalamus (Deleuze et al., 2012; Hong et al., 2014). T-type $\mathrm{Ca}^{2+}$ channels may act as a compensation mechanism to help maintain the responsivity of Calb- dopamine neurons to excitatory synaptic stimulation during periods of hyperpolarizing inhibition.

\section{T-type current density differs between Calb + and Calb- neurons}

Our findings above show that $\mathrm{T}$-type $\mathrm{Ca}^{2+}$ channels can cause regenerative low-threshold depolarizations in Calb- neurons and that they contribute to the timing of AP output when cells are released from sustained hyperpolarization. However, it is unclear how long the cell must be hyperpolarized to recover T-type channels from inactivation. Furthermore, a comparison of voltageclamp recorded T-type currents in Calb + and Calb- SNc dopamine neurons would provide direct mechanistic insight into the differences in the ability of these neuronal subpopulations to generate low-threshold depolarizations. Therefore, we compared T-type currents recorded from Calb + and Calb - neurons in voltage clamp. We applied slow voltage ramps delivered from -70 to $-40 \mathrm{mV}(400 \mathrm{~ms})$ to activate T-type ramp currents in adult Calb + and Calb $-\mathrm{SNc}$ neurons (Fig. $8 A$ ). The raw current traces evoked by these slow voltage ramps show that the total current contains a prominent low-threshold component and was net inward in many Calb- neurons. The inward component increased in amplitude with the duration of the $-70 \mathrm{mV}$ recovery step (Fig. 8B). Plotting the leak-subtracted current by voltage, the inward peak falls between -50 and $-55 \mathrm{mV}$, consistent with a low-threshold T-type $\mathrm{Ca}^{2+}$ current (Fig. 8C).

We repeated the ramp protocol in the presence of TTA-P2 and used subtraction to isolate the component of the total current due T-type channels. Figure $8 E$ shows example TTA-P2-sensitive currents for Calb + and Calb - neurons for holding durations of 100 $\mathrm{ms}$ (left) and $26 \mathrm{~s}$ (right). To compare recovery of T-type ramp currents in Calb + and Calb - neurons, we plotted the averaged current amplitude between -52 and $-54 \mathrm{mV}$ for each trace against the duration of the recovery step. The amplitude of the T-type current increased with the duration of the recovery step in the Calb- neurons, but not in the Calb + neurons (Fig. $8 D$ ). Comparing the current densities $(\mathrm{pA} / \mathrm{pF})$, we found a significant difference between Calb $+(-0.02 \pm 0.04 \mathrm{pA} / \mathrm{pF} ; n=6$ cells from 4 mice) and Calb $-(-0.43 \pm 0.12 ; n=6$ cells from 5 mice $)$ neurons after the $600 \mathrm{~ms}$ recovery step (Mann-Whitney $U$ test, $p=0.002)$ and at the maximal (26 s) recovery duration (Calb + , $-0.17 \pm 0.08 \mathrm{pA} / \mathrm{pF} ;$ Calb,$--0.72 \pm 0.17 \mathrm{pA} / \mathrm{pF}$; Mann-Whitney $U$ test, $p=0.009)$. However, after a $100 \mathrm{~ms}$ recovery step, the Calb $+(-0.04 \pm 0.09 \mathrm{pA} / \mathrm{pF})$ and Calb $-(-0.17 \pm 0.09 \mathrm{pA} / \mathrm{pF})$ TTA-P2-sensitive currents did not show a significant difference (Mann-Whitney $U$ test, $p=0.18$; Fig. $8 F$ ). These results demonstrate that Calb + and Calb - neurons have different densities of T-type current, and that subpopulation differences are apparent even with mild, subsecond hyperpolarizations.

To compare T-type activation to L-type activation in this voltage range, we applied nifedipine $(10 \mu \mathrm{M})$ to adult TH-GFP neurons, which exhibited low-threshold depolarizations, during the voltage ramp protocol. Nifedipine-sensitive currents were clear at more depolarized voltages $(>-50 \mathrm{mV})$, and did not depend on the holding duration. By contrast, TTA-P2-sensitive currents 


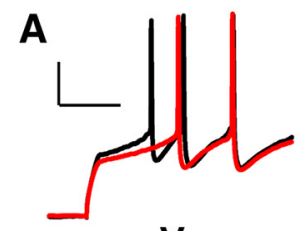

$-76 \mathrm{mV} \quad \mathrm{Vm}$

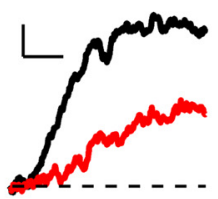

Ca2+
B
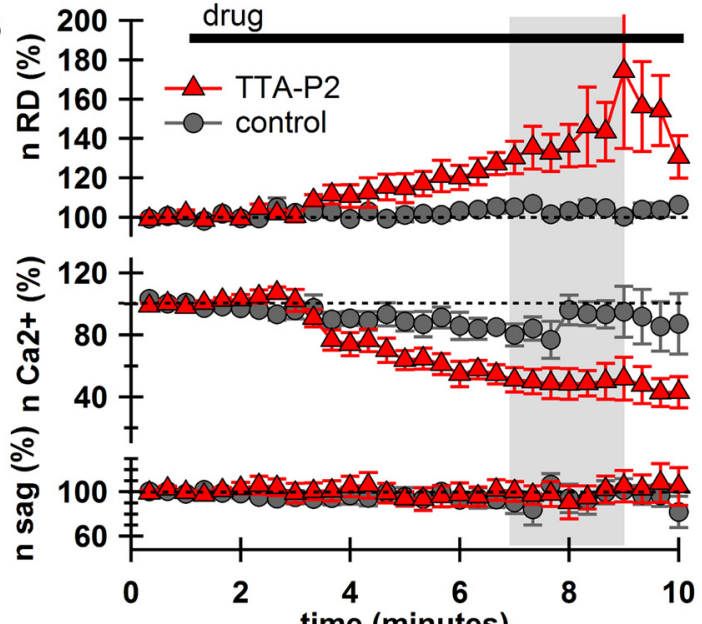

C
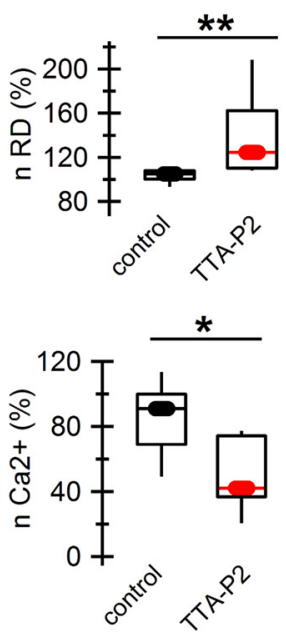

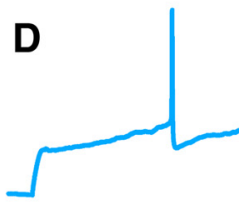

$-76 \mathrm{mV}$

$-78 m V$

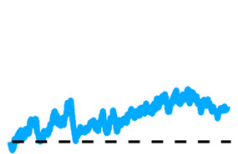

Calb+
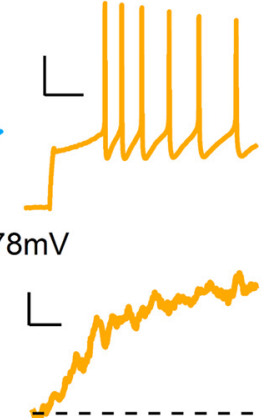

Calb-
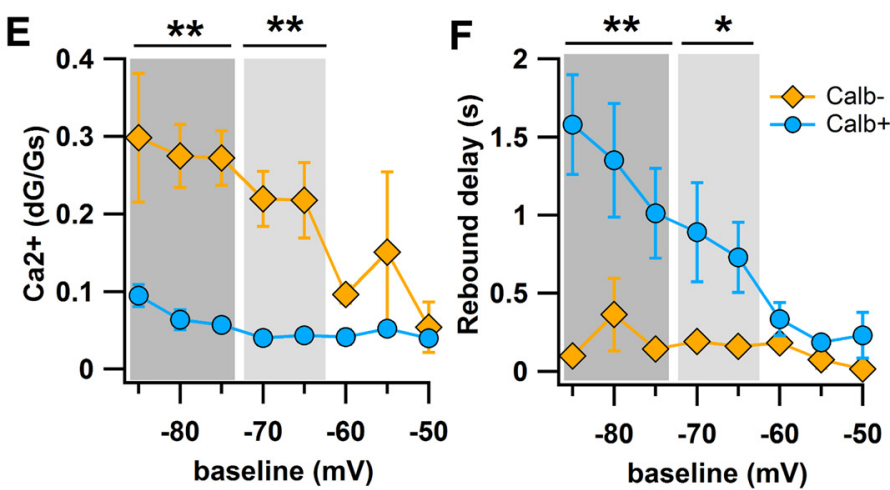

G

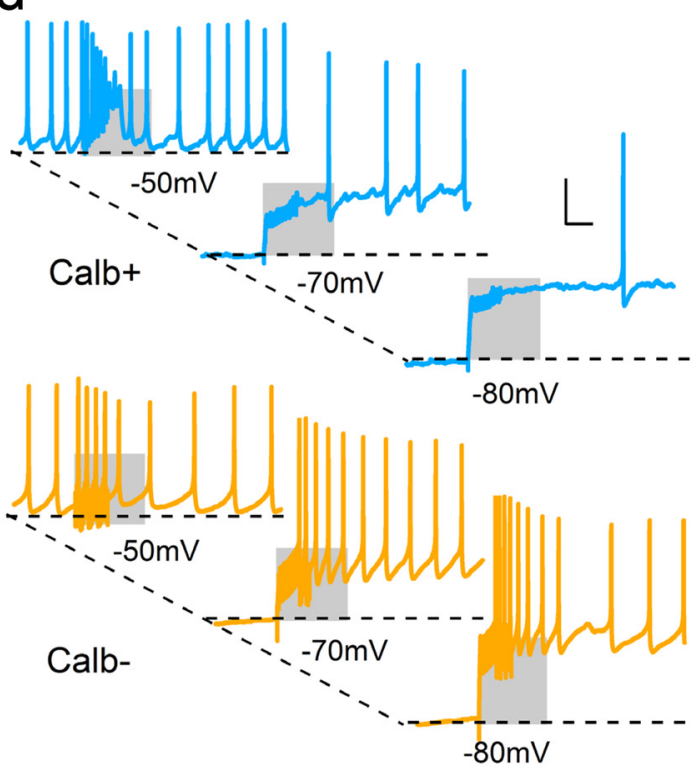

H I (pA)

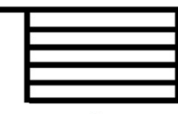

1s
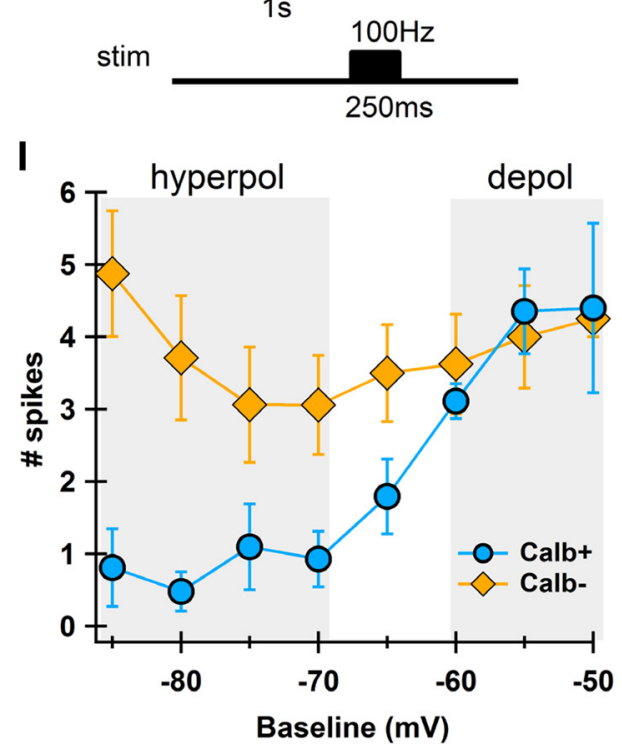

Figure 7. T-type $\mathrm{Ca}^{2+}$ channels contribute to rebound spike timing. $A$, Rebound spikes (top) and rebound $\mathrm{Ca}^{2+}$ (bottom) before (black) and after (red) TTA-P2 application. Scale bars: top, 20 $\mathrm{mV}, 100 \mathrm{~ms}$; bottom, $0.05 \mathrm{dG} / \mathrm{Gs}, 100 \mathrm{~ms}$. B. Time course of TTA-P2 application for rebound delay (top), rebound $\mathrm{Ca}^{2+}$ (middle), and sag amplitude (bottom). $n$ RD, Normalized rebound delay; $\mathrm{n}$ $\mathrm{Ca}^{2+}$, normalized $\mathrm{Ca}^{2+}$ amplitude; $\mathrm{n}$ sag, normalized sag amplitude. C, Summarized data from shaded areas in $\boldsymbol{B} .{ }^{* *} p<0.01{ }^{*} p<0.05$. D, Example rebound spikes (top) and rebound $\mathrm{Ca}{ }^{2+}$ (bottom) from membrane potentials close to $-80 \mathrm{mV}$ for a Calb + and a Calb - neuron. Scale bars: top, $20 \mathrm{mV}, 100 \mathrm{~ms}$; bottom, $0.05 \mathrm{dG} / \mathrm{Gs}, 100 \mathrm{~ms}$. E, Amplitude of Ca ${ }^{2+}$ signal versus baseline voltage in Calb - (yellow symbols) and Calb + (blue symbols) neurons. ${ }^{* *} p<0.01$. $F$, Rebound delay versus baseline voltage for Calb + , but not Calb - , neurons. Statistics reported in the text are from shaded areas. ${ }^{*} p<0.05,{ }^{* *} p<0.01$. G, Example traces showing rebound burst responses to stimulation at different levels of hyperpolarization for Calb + and Calb - neurons. Shaded area represents rebound time period (500 ms). Scale bars: $20 \mathrm{mV}, 200 \mathrm{~ms}$. $\boldsymbol{H}$, Rebound burst protocol. I, Average number of rebound spikes versus baseline voltage. Statistics reported in text compare hyperpolarized potentials (hyperpol) to depolarized potentials (depol). Data are presented as mean \pm SEM. 
A

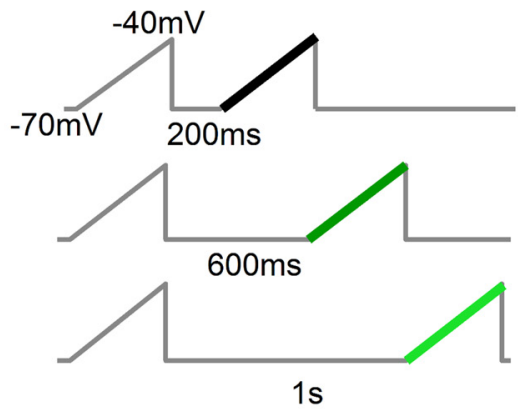

1s

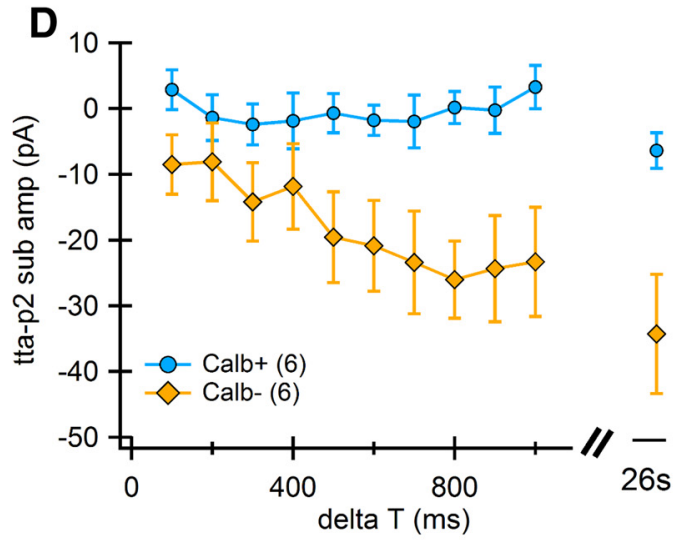

G

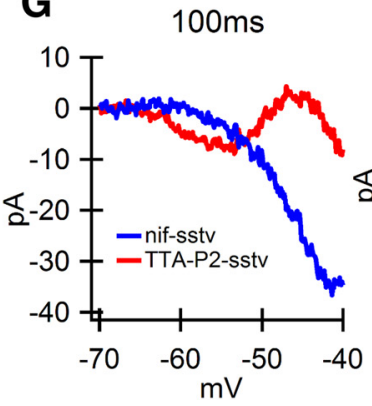

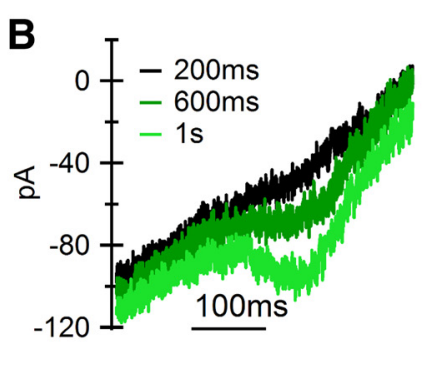

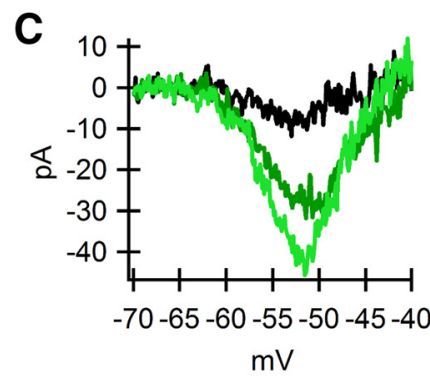

$\mathrm{mV}$
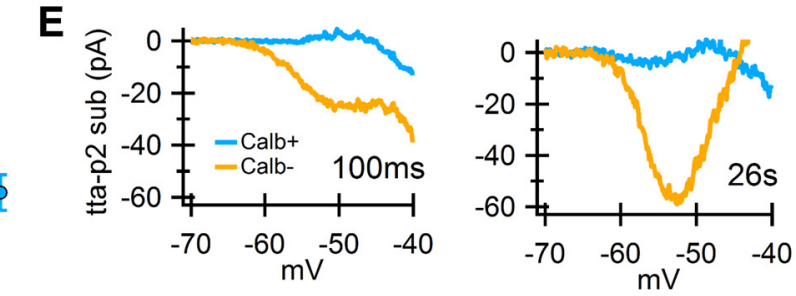
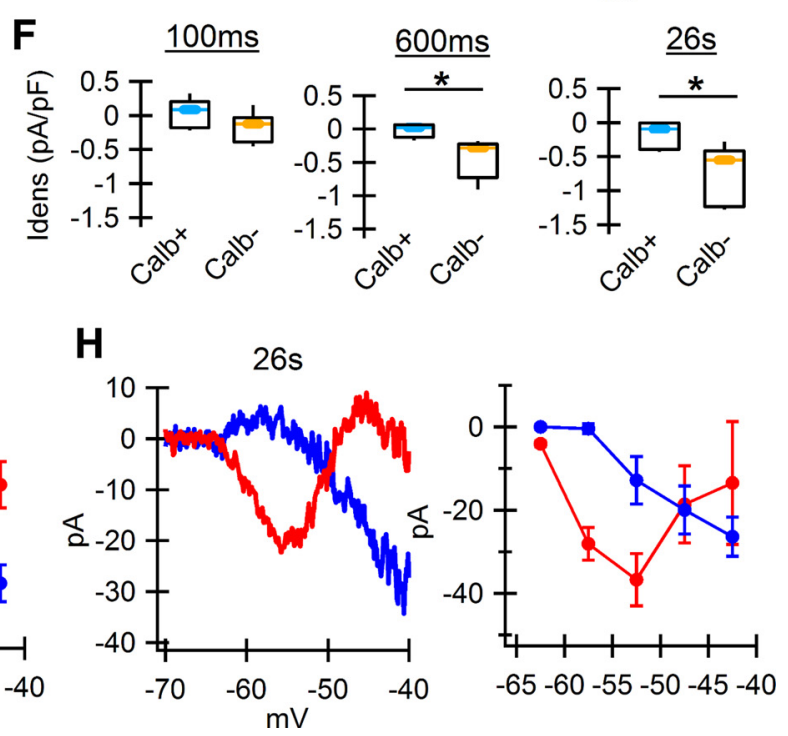

Figure 8. T-type $\mathrm{Ca}^{2+}$ channels are activated by voltage ramps. $A$, Voltage-clamp ramp protocol. Four hundred millisecond ramps from -70 to $-40 \mathrm{mV}$ were run after varying the duration of the recovery step $(-70 \mathrm{mV})$. $\boldsymbol{B}$, Raw current traces from times shown in $\boldsymbol{A}$. C, Same currents as in $\boldsymbol{B}$, but leak subtracted and plotted by voltage. $\boldsymbol{D}$, Amplitude of TTA-P2-subtracted current plotted by duration of recovery step. Maximal holding duration was the intersweep interval of $26 \mathrm{~s}$. Data presented as mean \pm SEM. $E$, Example TTA-P2-subtracted traces from Calb + and Calb - neurons after $100 \mathrm{~ms}$ (left) and $26 \mathrm{~s}$ (right) durations of $-70 \mathrm{mV}$ holding potential. $F$, Summary of current density (Idens; $\mathrm{pA} / \mathrm{pF}$ ) amplitude from TTA-P2-sensitive currents. ${ }^{*} p<0.01$. G, Example trace from a TH-GFP mouse showing the nifedipine-sensitive (nif-sstv; $10 \mu \mathrm{M}$ ) and TTA-P2-sensitive (TTAP2-sstv; $1 \mu \mathrm{M}$ ) ramp currents from the same cell (left). Current traces from six TH-positive neurons, which displayed low-threshold depolarizations, binned by voltage and averaged. Ramp currents were evoked after $100 \mathrm{~ms}$ recovery step. $\boldsymbol{H}$, Same as $\boldsymbol{G}$, but with ramp currents evoked after $26 \mathrm{~s}$ recovery step. Data are from adult mice and are presented as mean \pm SEM.

were present at more hyperpolarized voltages, where they increased in amplitude following longer holding durations at -70 $\mathrm{mV}$ (Fig. 8G,H). These results confirm that the low-threshold component of this ramp current is due to T-type rather than L-type current, and demonstrate a clear difference in sensitivity to holding duration and activation voltage between these two currents in SNc dopamine neurons.

\section{Dopamine-mediated hyperpolarization differentially effects \\ Calb + and Calb - neurons}

Dopamine neurons release dopamine from their dendrites and soma. Somatodendritically released dopamine opens potassium (GIRK) channels by activating D2-dopamine receptors, hyperpolarizing dopamine neurons (Beckstead et al., 2004; Dragicevic et al., 2014). Previous studies have demonstrated that $\mathrm{Ca}^{2+}$ can inhibit D2-mediated GIRK currents and can modulate D2receptor desensitization (Kramer and Williams, 2016; Gantz et al., 2015; Poetschke et al., 2015; Dragicevic et al., 2014). We tested whether D2-receptors recruitment of GIRK currents is sufficient to hyperpolarize neurons and enable low-threshold depolarizations under weak $\mathrm{Ca}^{2+}$ buffering condition (300 micromolar Fluo5F). Quinpirole $(10-50 \mu \mathrm{M})$, a D2-receptor agonist, was puffed onto SNc neurons. During quinpirole application (1-3 min), a low-threshold depolarization was evoked by the AP triplet (Fig. 9A, top), and a large dendritic $\mathrm{Ca}^{2+}$ signal was observed (Fig. 9A, bottom). As the cell depolarized, the size of the lowthreshold depolarization and the $\mathrm{Ca}^{2+}$ amplitude decreased, leaving depolarizations that occurred in a more graded manner. In an average of 6 wild-type neurons (from 4 mice), quinpirolemediated hyperpolarization increased AUC and dendritic $\mathrm{Ca}^{2+}$ amplitude (Fig. 9B). Cells where quinpirole application failed to hyperpolarize the neurons below $-60 \mathrm{mV}$ were not used. Plotting the AUC or the $\mathrm{Ca}^{2+}$ amplitude by membrane potential reveals that quinpirole-mediated hyperpolarization increased 
both AUC and dendritic $\mathrm{Ca}^{2+}$ amplitude for a number of cells (Fig. 9C). These results show that activation of endogenous D2-dopamine receptors can hyperpolarize dopamine neurons sufficiently to recover T-type currents.

D2-receptor mRNA is more strongly expressed in the SNc than the VTA (Hurd et al., 1994) and the GIRK currents activated by dopamine appear larger in the SNc than in the VTA (Sharpe et al., 2014). However, it is not known whether the $\mathrm{Calb}+$ and Calb - neurons of the SNc differ in their response to dopamine. Therefore, dopamine iontophoresis (8 s) was applied to the soma of Calb + and Calbneurons while the soma was repeatedly depolarized by small subthreshold current injection ( 10 pulses, 3 ms width, 200 pA, $5 \mathrm{~ms}$ interstimulus interval). Dopamine iontophoresis resulted in fast-acting membrane hyperpolarization in both subpopulations. Cells that did not hyperpolarize to $\geq-60 \mathrm{mV}$ ( 1 of $10 \mathrm{Calb}-$ and 2 of 8 Calb + neurons) were not used. On average, the extent of dopaminemediated hyperpolarization was similar in Calb $+(-67.8 \pm 1.3 \mathrm{mV}, n=6$ cells from 6 mice $)$ and Calb $-(-66.7 \pm 1.1 \mathrm{mV}, n=$ 9 cells from 6 mice) dopamine neurons (Mann-Whitney $U$ test, $p=0.39$ ). In the presence of dopamine, the subthreshold depolarizing current was sufficient to generate low-threshold depolarizations in Calb - neurons [AUC, $3.1 \pm 0.5 \mathrm{mV}^{\star} \mathrm{s}$, $n=9$ cells from 6 mice), but not Calb+ neurons (AUC, $1.09 \pm 0.09 \mathrm{mV}^{\star} \mathrm{s}, n=6$ cells from 6 mice; Mann-Whitney $U$ test, $p=0.0008$; Fig. $10 A, B$ ). Interestingly, the low-threshold depolarizations could occur in a graded manner, with depolarizing stimuli early in the iontophoresis protocol often showing "partial" low-threshold depolarizations (Fig. $10 C$ ), likely due to incomplete recovery of T-type channels.

Altogether, these results demonstrate that dopamine hyperpolarizes both Calb + and Calb - neurons, but selectively increases the sensitivity of Calb- neurons to depolarizing input through recruitment of T-type $\mathrm{Ca}^{2+}$ channels.

\section{Discussion}

Calb + and Calb - dopamine neurons are distinct

SNc subpopulations

Here, we report that $\mathrm{Ca}^{2+}$ channel composition differs between the ventral tier $\mathrm{Calb}-$ and dorsal tier Calb + neurons within the SNc, which results in differences in their physiological response to dopamine. We show that dopamine-mediated hyperpolarization results in the amplification of excitatory signals and enables low-threshold depolarizations and large dendritic $\mathrm{Ca}^{2+}$ signals selectively in the Calb- subpopulation. These low-threshold depolarizations can occur in a graded manner at moderately hyperpolarized potentials $(-70$ to $-60 \mathrm{mV}$ ) due to recruitment of T-type $\mathrm{Ca}^{2+}$ channels. We show that T-type $\mathrm{Ca}^{2+}$ currents contribute to a rapid recovery of firing following hyperpolarization in Calb - neurons. Voltage-clamp recordings of ramp currents reveal a high density of T-type current in Calb- neurons with relatively little present in Calb + neurons. Altogether, these results show that Calb + and Calb $-\mathrm{SNc}$ dopamine neurons differ in their response to dopamine D2-receptor autoinhibition due to differential expression of T-type current.

These findings support that idea that Calb + and Calb - dopamine neurons within the SNc form functionally distinct populations that likely transmit separate dopamine signals to the striatum. Important prior studies that also support this idea have reported cellular differences in the expression of $I_{\mathrm{h}}$ (Neuhoff et al., 2002), as well as differences in tonic and burst firing during in vivo experiments (Schiemann et al., 2012). Further evidence for parallel signaling between dorsal and ventral tier SNc dopamine neurons comes from anatomical studies showing that the axonal projections of Calb - neurons tend to target patch compartments while Calb + neurons prefer to innervate the matrix (Gerfen et al., 1987; Prensa and Parent, 2001; Bentivoglio and Morelli, 2005; Matsuda et al., 2009).

Our results clearly show subpopulation differences, with the $\mathrm{Ca}^{2+}$ amplitudes from Calb + neurons forming a discrete cluster 

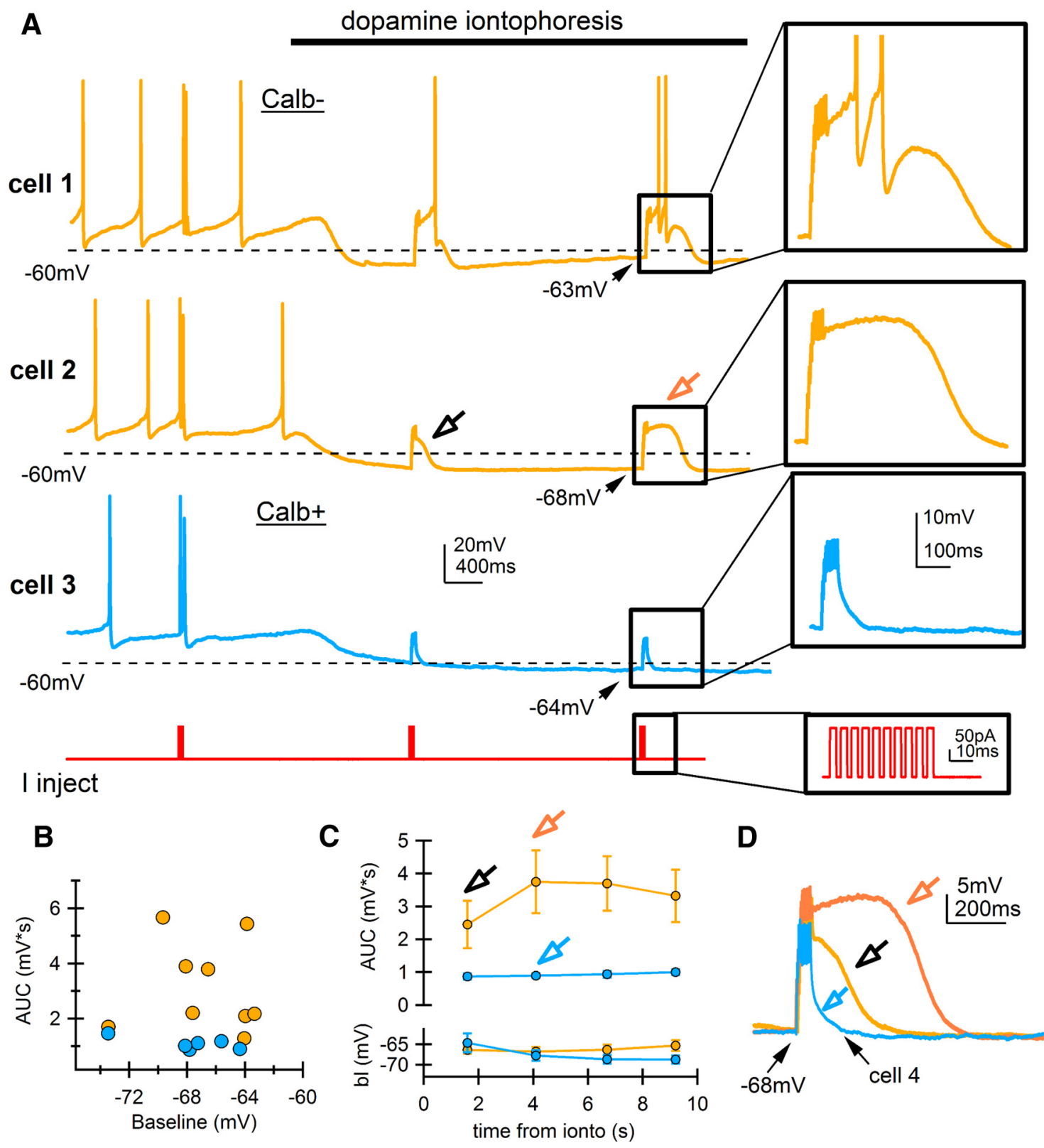

Figure 10. Dopamine differentially modulates Calb + and Calb - neurons. A, Example traces of activity in two Calb - (yellow) and one Calb + (blue) SNc dopamine neurons during dopamine iontophoresis. Depolarizing input trains (10 pulses, $200 \mathrm{pA}$ ) were applied periodically to cells (I inject). B, AUC for all Calb + (blue) and Calb - (yellow) neurons during dopamine iontophoresis plotted by baseline membrane potential (Baseline). C, AUC and baseline voltage (bl) for Calb + (blue) and Calb - (yellow) neurons measured at different time points from start of iontophoresis. Data are presented as means \pm SEM. Error bars fall within symbols. $\boldsymbol{D}$, Example traces from cell 2 at an early (yellow) and a later time point (orange). Blue trace is from a Calb + cell. Open arrows correspond to time points indicated in $\boldsymbol{C}$.

of data points (Fig. 2E). However, the data from Calb- neurons tended to span a wider range of values in their low-threshold depolarization amplitudes and dendritic $\mathrm{Ca}^{2+}$ signals (Fig. 2E), suggesting that additional diversity may exist within the Calbsubpopulation. The possibility that additional subpopulations exist is supported by in vivo experiments showing that lateral and medial dopamine neurons exhibit differences in ATP-sensitive potassium $\left(\mathrm{K}_{\mathrm{ATP}}\right)$ channel-dependent bursting (Schiemann et al., 2012) and responses to aversive stimuli (Matsumoto and Hikosaka, 2009; Lerner et al., 2015). These studies did not investigate responses in the Calb + and Calb - subpopulations (but see Brown et al., 2009), but found that the lateral SNc neurons were excited by aversive stimuli, while medial SNc neurons were inhibited. Interestingly, Lerner et al. (2015) found that inhibited neurons displayed a subsequent rebound $\mathrm{Ca}^{2+}$ signal. Fiorillo et al. (2013) compared rebound activity after aversive pauses between dorsal and ventral SNc neurons and found that rebound excitation occurred selectively in the ventral SNc neurons, suggesting that the ventral Calb- neurons are more likely to rebound in vivo.

In addition to the differential response to rewarding and aversive stimuli, behavioral studies have shown that subsets of dopamine neurons were activated or inactivated at movement onset (Jin and Costa, 2010; Dodson et al., 2016). This work has been corroborated by $\mathrm{Ca}^{2+}$ imaging studies both in mice and in flies that show that separate subsets of dopamine neurons are selectively activated by either reward or movement (Cohn et al., 2015; Howe and Dombeck, 2016). Future work is needed to determine 
whether the subpopulations defined by differential in vivo activity correspond to the Calb - and Calb + neurons, or whether they represent further diversity within the $\mathrm{Calb}-$ subpopulation.

\section{Interactions of T-type $\mathrm{Ca}^{2+}$ currents with $I_{\mathrm{h}}$}

We have shown that T-type current density is larger in Calb- SNc neurons than Calb + SNc neurons, and that this difference profoundly alters these subpopulations' responses to excitation from hyperpolarized potentials. However, other hyperpolarizationdependent currents, such as $I_{\mathrm{h}}$, also differ between these subpopulations (Fig. 3F; Neuhoff et al., 2002). While T-type current and $I_{\mathrm{h}}$ may seem to perform similar functions in their strengthening of rebound firing (Fig. 7), studies in other neuronal cell types have described opposing roles for T-type currents and $I_{\mathrm{h}}$ in control of dendritic excitability. For example, dendritic T-type current broadens the time window for synaptic integration (Egger, 2008) while $I_{\mathrm{h}}$ shortens it (Magee, 1998). In CA1 cells, $I_{\mathrm{h}}$ inhibits excitability of the distal dendrites by depolarizing the membrane potential, which leads to inactivation of distally located T-type channels (Tsay et al., 2007). Although $I_{\mathrm{h}}$ has been shown to limit dendritic excitability in SNc dopamine neurons (Engel and Seutin, 2015), we show that dopamine D2-autoreceptor inhibition can provide sufficient hyperpolarization to recover T-type $\mathrm{Ca}^{2+}$ currents and enable amplification of excitatory inputs in Calbneurons.

\section{Functional role for T-type $\mathrm{Ca}^{2+}$ channels in Calb- SNc neurons}

In considering the function of the high density of T-type current in Calb- SNc neurons, it is important to understand the physiological mechanisms that can hyperpolarize dopamine neurons to strongly recruit T-type currents and enable low-threshold depolarizations. SNc dopamine neurons can be hyperpolarized by incoming inhibitory signals, activating both GABAa and GABAb receptors, by D2-receptor autoinhibition, and through Katp channels, which will hyperpolarize them during periods of metabolic stress. Because the chloride reversal potential in dopamine neurons is relatively depolarized ( -62 to $-69 \mathrm{mV}$; Grace and Bunney, 1985; Gulácsi et al., 2003), GABA A inhibition most likely occurs through a shunting mechanism rather than through direct hyperpolarization. Therefore, as in the cerebellum (Alviña et al., 2008; Zheng and Raman, 2009), GABA is not likely to strongly recruit T-type channels or facilitate low-threshold depolarizations. Alternatively, dopamine D2-autoreceptors and $\mathrm{GABA}_{\mathrm{B}}$ receptors can potently hyperpolarize $\mathrm{SNc}$ dopamine neurons. Both $D 2$ and $G_{A B A}$ receptors couple to GIRK channels that can drive the membrane potential close to the potassium reversal potential. We demonstrate in Figures 9 and 10 that D2-receptor activation can generate sufficient hyperpolarization to effectively engage T-type current and enable regenerative low-threshold depolarizations. Physiologically, dopamine is released through dendrodendritic synapses between dopamine neurons (Chen and Rice, 2002; Beckstead et al., 2004; Gantz et al., 2013) and a global increase in dopaminergic tone could be achieved through blocking dopamine reuptake with cocaine (Lacey et al., 1990). Therefore, GIRK-dependent hyperpolarization represents a physiological mechanism for the effective recruitment of T-type $\mathrm{Ca}^{2+}$ channels.

In addition to showing that strong hyperpolarization can effectively recover T-type channels from inactivation and enable regenerative $\mathrm{Ca}^{2+}$ events, we propose that T-type currents may contribute to the activity of Calb- SNc neurons when partially recovered from inactivation. Our voltage-clamp recordings dem- onstrate the presence of a T-type $\mathrm{Ca}^{2+}$ channel-mediated ramp current active during voltage ramps from -70 to $-40 \mathrm{mV}$ in Calb- SNc dopamine neurons (Fig. 8). These findings are consistent with data from the thalamus (Dreyfus et al., 2010) and locus ceruleus (Matschke et al., 2015) reporting observations of a T-type "window current," which is a small, subthreshold current thought to result from overlap of activation and inactivation curves. In locus ceruleus neurons, T-type window currents in conjunction with current from L-type $\mathrm{Ca}^{2+}$ channels have been shown to contribute to the robustness of pacemaking (Matschke et al., 2015). Although our experiments in SNc dopamine neurons do not directly test the role of T-type currents in pacemaking, two existing studies show clear effects of pharmacological block of T-type channels on spontaneous firing in SNc neurons. Wolfart and Roeper (2002) found that T-type channels contribute to the regularity of pacemaking in cells from juvenile mice through coupling to calcium-activated potassium channels, while Poetschke et al. (2015) found that block of T-type current slowed pacemaking by $30 \%$ in adult dopamine neurons. Our voltage-clamp results are consistent with a role for T-type channels in spontaneous pacemaking, but predict that such a role would be limited to the Calb-SNc subpopulation.

\section{Conclusion}

Our work shows that the Calb + and Calb-SNc dopamine neurons represent distinct subpopulations that differ in their $\mathrm{Ca}^{2+}$ channel composition. The Calb - SNc neurons have a paradoxical increase in dendritic excitability in response to D2-mediated hyperpolarization due to their higher density of T-type $\mathrm{Ca}^{2+}$ current. The higher expression of both T-type current and $I_{\mathrm{h}}$ allows Calb - neurons to recover more quickly from periods of inhibition and may facilitate rebound bursts. By contrast, Calb+ neurons will be strictly inhibited by hyperpolarization and likely require strong excitatory synaptic activity to burst or to return to tonic firing. These differential responses to hyperpolarization may reflect differences in function. For example, if dopamine released from the Calb- neurons is important for movement, the ability to quickly return to tonic firing after or during a period of inhibition may be essential for maintaining tonic levels of dopamine in the striatum. Similarly, if dopamine from Calb + neurons is important for signaling rewarding or aversive events, the ability to be effectively silenced by inhibition may be critical for the timing of learning signals.

\section{References}

Aizenman CD, Linden DJ (1999) Regulation of the rebound depolarization and spontaneous firing patterns of deep nuclear neurons in slices of rat cerebellum. J Neurophysiol 82:1697-1709.

Alviña K, Walter JT, Kohn A, Ellis-Davies G, Khodakhah K (2008) Questioning the role of rebound firing in the cerebellum. Nat Neurosci 11: 1256-1258. CrossRef Medline

Amendola J, Woodhouse A, Martin-Eauclaire MF, Goaillard JM (2012) $\mathrm{Ca}^{2+} /$ cAMP-sensitive covariation of $I_{\mathrm{A}}$ and $I_{\mathrm{H}}$ voltage dependences tunes rebound firing in dopaminergic neurons. J Neurosci 32:2166-2181. CrossRef Medline

Anderegg A, Poulin JF, Awatramani R (2015) Molecular heterogeneity of midbrain dopaminergic neurons-moving toward single cell resolution. FEBS Lett 589:3714-3726. CrossRef Medline

Aransay A, Rodríguez-López C, García-Amado M, Clascá F, Prensa L (2015) Long-range projection neurons of the mouse ventral tegmental area: a single-cell axon tracing analysis. Front Neuroanat 9:59. CrossRef Medline

Beckstead MJ, Grandy DK, Wickman K, Williams JT (2004) Vesicular dopamine release elicits an inhibitory postsynaptic current in midbrain dopamine neurons. Neuron 42:939-946. CrossRef Medline

Beier KT, Steinberg EE, DeLoach KE, Xie S, Miyamichi K, Schwarz L, Gao XJ, 
Kremer EJ, Malenka RC, Luo L (2015) Circuit architecture of VTA dopamine neurons revealed by systematic input-output mapping. Cell 162: 622-634. CrossRef Medline

Bentivoglio M, Morelli M (2005) Chapter I: the organization and circuits of mesencephalic dopaminergic neurons and the distribution of dopamine receptors in the brain. In: Handbook of chemical neuroanatomy (Dunnett SB, Björklund, Hökfelt T, eds), pp 1-107. Amsterdam: Elsevier.

Brown MT, Henny P, Bolam JP, Magill PJ (2009) Activity of neurochemically heterogeneous dopaminergic neurons in the substantia nigra during spontaneous and driven changes in brain state. J Neurosci 29:2915-2925. CrossRef Medline

Cardozo DL, Bean BP (1995) Voltage-dependent calcium channels in rat midbrain dopamine neurons: modulation by dopamine and GABAB receptors. J Neurophysiol 74:1137-1148. Medline

Chan CS, Guzman JN, Ilijic E, Mercer JN, Rick C, Tkatch T, Meredith GE, Surmeier DJ (2007) "Rejuvenation" protects neurons in mouse models of Parkinson's disease. Nature 447:1081-1086. CrossRef Medline

Chen BT, Rice ME (2002) Synaptic regulation of somatodendritic dopamine release by glutamate and GABA differs between substantia nigra and ventral tegmental area. J Neurochem 81:158-169. CrossRef Medline

Cohn R, Morantte I, Ruta V (2015) Coordinated and compartmentalized neuromodulation shapes sensory processing in Drosophila. Cell 163: 1742-1755. CrossRef Medline

Connelly WM, Crunelli V, Errington AC (2015) The global spike: conserved dendritic properties enable unique $\mathrm{Ca}^{2+}$ spike generation in low-threshold spiking neurons. J Neurosci 35:15505-15522. CrossRef Medline

Damier P, Hirsch EC, Agid Y, Graybiel AM (1999) The substantia nigra of the human brain. II. Patterns of loss of dopamine-containing neurons in Parkinson's disease. Brain 122:1437-1448. CrossRef Medline

Deleuze C, David F, Béhuret S, Sadoc G, Shin HS, Uebele VN, Renger JJ, Lambert RC, Leresche N, Bal T (2012) T-type calcium channels consolidate tonic action potential output of thalamic neurons to neocortex. J Neurosci 32:12228-12236. CrossRef Medline

Dodson PD, Dreyer JK, Jennings KA, Syed EC, Wade-Martins R, Cragg SJ, Bolam JP, Magill PJ (2016) Representation of spontaneous movement by dopaminergic neurons is cell-type selective and disrupted in parkinsonism. Proc Natl Acad Sci U S A 113:E2180-E2188. CrossRef Medline

Dopeso-Reyes IG, Rico AJ, Roda E, Sierra S, Pignataro D, Lanz M, Sucunza D, Chang-Azancot L, Lanciego JL (2014) Calbindin content and differential vulnerability of midbrain efferent dopaminergic neurons in macaques. Front Neuroanat 8:146. CrossRef Medline

Dragicevic E, Poetschke C, Duda J, Schlaudraff F, Lammel S, Schiemann J, Fauler M, Hetzel A, Watanabe M, Lujan R, Malenka RC, Striessnig J, Liss B (2014) Cav1.3 channels control D2-autoreceptor responses via NCS-1 in substantia nigra dopamine neurons. Brain 137:2287-2302. CrossRef Medline

Dreyfus FM, Tscherter A, Errington AC, Renger JJ, Shin HS, Uebele VN, Crunelli V, Lambert RC, Leresche N (2010) Selective T-type calcium channel block in thalamic neurons reveals channel redundancy and physiological impact of $I_{\text {Twindow. }}$ J Neurosci 30:99-109. CrossRef Medline

Dryanovski DI, Guzman JN, Xie Z, Galteri DJ, Volpicelli-Daley LA, Lee VM, Miller RJ, Schumacker PT, Surmeier DJ (2013) Calcium entry and $\alpha$-synuclein inclusions elevate dendritic mitochondrial oxidant stress in dopaminergic neurons. J Neurosci 33:10154-10164. CrossRef Medline

Dufour MA, Woodhouse A, Goaillard JM (2014) Somatodendritic ion channel expression in substantia nigra pars compacta dopaminergic neurons across postnatal development. J Neurosci Res 92:981-999. CrossRef Medline

Egger V (2008) Synaptic sodium spikes trigger long-lasting depolarizations and slow calcium entry in rat olfactory bulb granule cells. Eur J Neurosci 27:2066-2075. CrossRef Medline

Engel D, Seutin V (2015) High dendritic expression of $I_{\mathrm{H}}$ in the proximity of the axon origin controls the integrative properties of nigral dopamine neurons. J Physiol 593:4905-4922. CrossRef Medline

Fallon JH, Moore RY (1978) Catecholamine innervation of the basal forebrain. IV. Topography of the dopamine projection to the basal forebrain and neostriatum. J Comp Neurol 180:545-580. CrossRef Medline

Fiorillo CD, Yun SR, Song MR (2013) Diversity and homogeneity in responses of midbrain dopamine neurons. J Neurosci 33:4693-4709. CrossRef Medline

Ford CP, Mark GP, Williams JT (2006) Properties and opioid inhibition of mesolimbic dopamine neurons vary according to target location. J Neurosci 26:2788-2797. CrossRef Medline

Gantz SC, Bunzow JR, Williams JT (2013) Spontaneous inhibitory synaptic currents mediated by a $\mathrm{G}$ protein-coupled receptor. Neuron 78:807-812. CrossRef Medline

Gantz SC, Robinson BG, Buck DC, Bunzow JR, Neve RL, Williams JT, Neve KA (2015) Distinct regulation of dopamine D2S and D2L autoreceptor signaling by calcium. Elife 4 . CrossRef Medline

Geisler S, Zahm DS (2005) Afferents of the ventral tegmental area in the rat-anatomical substratum for integrative functions. J Comp Neurol 490: 270-294. CrossRef Medline

Gentet LJ, Williams SR (2007) Dopamine gates action potential backpropagation in midbrain dopaminergic neurons. J Neurosci 27:1892-1901. CrossRef Medline

Gerfen CR, Herkenham M, Thibault J (1987) The neostriatal mosaic: II. Patchand matrix-directed mesostriatal dopaminergic and non-dopaminergic systems. J Neurosci 7:3915-3934. Medline

Grace AA, Bunney BS (1985) Opposing effects of striatonigral feedback pathways on midbrain dopamine cell activity. Brain Res 333:271-284. CrossRef Medline

Gulácsi A, Lee CR, Sík A, Viitanen T, Kaila K, Tepper JM, Freund TF (2003) Cell type-specific differences in chloride-regulatory mechanisms and $\mathrm{GABA}_{\mathrm{A}}$ receptor-mediated inhibition in rat substantia nigra. J Neurosci 23:8237-8246. Medline

Guzman JN, Sánchez-Padilla J, Chan CS, Surmeier DJ (2009) Robust pacemaking in substantia nigra dopaminergic neurons. J Neurosci 29:1101111019. CrossRef Medline

Hage TA, Khaliq ZM (2015) Tonic firing rate controls dendritic $\mathrm{Ca}^{2+}$ signaling and synaptic gain in substantia nigra dopamine neurons. J Neurosci 35:5823-5836. CrossRef Medline

Helton TD, Xu W, Lipscombe D (2005) Neuronal L-type calcium channels open quickly and are inhibited slowly. J Neurosci 25:10247-10251. CrossRef Medline

Hnasko TS, Hjelmstad GO, Fields HL, Edwards RH (2012) Ventral tegmental area glutamate neurons: electrophysiological properties and projections. J Neurosci 32:15076-15085. CrossRef Medline

Hong SZ, Kim HR, Fiorillo CD (2014) T-type calcium channels promote predictive homeostasis of input-output relations in thalamocortical neurons of lateral geniculate nucleus. Front Comput Neurosci 8:98. CrossRef Medline

Howe MW, Dombeck DA (2016) Rapid signalling in distinct dopaminergic axons during locomotion and reward. Nature 535:505-510. CrossRef Medline

Hurd YL, Pristupa ZB, Herman MM, Niznik HB, Kleinman JE (1994) The dopamine transporter and dopamine D2 receptor messenger RNAs are differentially expressed in limbic- and motor-related subpopulations of human mesencephalic neurons. Neuroscience 63:357-362. CrossRef Medline

Jahnsen H, Llinás R (1984) Electrophysiological properties of guinea-pig thalamic neurones: an in vitro study. J Physiol 349:205-226. CrossRef Medline

Jin X, Costa RM (2010) Start/stop signals emerge in nigrostriatal circuits during sequence learning. Nature 466:457-462. CrossRef Medline

Kang Y, Kitai ST (1993a) Calcium spike underlying rhythmic firing in dopaminergic neurons of the rat substantia nigra. Neurosci Res 18:195-207. CrossRef Medline

Kang Y, Kitai ST (1993b) A whole cell patch-clamp study on the pacemaker potential in dopaminergic neurons of rat substantia nigra compacta. Neurosci Res 18:209-221. CrossRef Medline

Khaliq ZM, Bean BP (2010) Pacemaking in dopaminergic ventral tegmental area neurons: depolarizing drive from background and voltage-dependent sodium conductances. J Neurosci 30:7401-7413. CrossRef Medline

Kim JI, Ganesan S, Luo SX, Wu YW, Park E, Huang EJ, Chen L, Ding JB (2015) Aldehyde dehydrogenase lal mediates a GABA synthesis pathway in midbrain dopaminergic neurons. Science 350:102-106. CrossRef Medline

Kramer PF, Williams JT (2016) Calcium release from stores inhibits GIRK. Cell Rep 17:3246-3255. CrossRef Medline

Lacey MG, Mercuri NB, North RA (1990) Actions of cocaine on rat dopaminergic neurones in vitro. Br J Pharmacol 99:731-735. CrossRef Medline

Lammel S, Hetzel A, Häckel O, Jones I, Liss B, Roeper J (2008) Unique 
properties of mesoprefrontal neurons within a dual mesocorticolimbic dopamine system. Neuron 57:760-773. CrossRef Medline

Lerner TN, Shilyansky C, Davidson TJ, Evans KE, Beier KT, Zalocusky KA, Crow AK, Malenka RC, Luo L, Tomer R, Deisseroth K (2015) Intactbrain analyses reveal distinct information carried by SNc dopamine subcircuits. Cell 162:635-647. CrossRef Medline

Liu G, Yu J, Ding J, Xie C, Sun L, Rudenko I, Zheng W, Sastry N, Luo J, Rudow G, Troncoso JC, Cai H (2014) Aldehyde dehydrogenase 1 defines and protects a nigrostriatal dopaminergic neuron subpopulation. J Clin Invest 124:3032-3046. CrossRef Medline

Llinás R, Greenfield SA, Jahnsen H (1984) Electrophysiology of pars compacta cells in the in vitro substantia nigra-a possible mechanism for dendritic release. Brain Res 294:127-132. CrossRef Medline

Magee JC (1998) Dendritic hyperpolarization-activated currents modify the integrative properties of hippocampal CA1 pyramidal neurons. J Neurosci 18:7613-7624. Medline

Maravall M, Mainen ZF, Sabatini BL, Svoboda K (2000) Estimating intracellular calcium concentrations and buffering without wavelength ratioing. Biophys J 78:2655-2667. CrossRef Medline

Margolis EB, Mitchell JM, Ishikawa J, Hjelmstad GO, Fields HL (2008) Midbrain dopamine neurons: projection target determines action potential duration and dopamine $\mathrm{D}(2)$ receptor inhibition. J Neurosci 28:89088913. CrossRef Medline

Matschke LA, Bertoune M, Roeper J, Snutch TP, Oertel WH, Rinné S, Decher N (2015) A concerted action of L- and T-type $\mathrm{Ca}(2+)$ channels regulates locus coeruleus pacemaking. Mol Cell Neurosci 68:293-302. CrossRef Medline

Matsuda W, Furuta T, Nakamura KC, Hioki H, Fujiyama F, Arai R, Kaneko T (2009) Single nigrostriatal dopaminergic neurons form widely spread and highly dense axonal arborizations in the neostriatum. J Neurosci 29:444-453. CrossRef Medline

Matsumoto M, Hikosaka O (2009) Two types of dopamine neuron distinctly convey positive and negative motivational signals. Nature 459: 837-841. CrossRef Medline

Menegas W, Bergan JF, Ogawa SK, Isogai Y, Umadevi Venkataraju K, Osten P, Uchida N, Watabe-Uchida M (2015) Dopamine neurons projecting to the posterior striatum form an anatomically distinct subclass. eLife 4:e10032. CrossRef Medline

Müller A, Kukley M, Stausberg P, Beck H, Müller W, Dietrich D (2005) Endogenous $\mathrm{Ca}^{2+}$ buffer concentration and $\mathrm{Ca}^{2+}$ microdomains in hippocampal neurons. J Neurosci 25:558-565. CrossRef Medline

Neuhoff H, Neu A, Liss B, Roeper J (2002) $I_{\mathrm{h}}$ channels contribute to the different functional properties of identified dopaminergic subpopulations in the midbrain. J Neurosci 22:1290-1302. Medline

Ogawa SK, Cohen JY, Hwang D, Uchida N, Watabe-Uchida M (2014) Organization of monosynaptic inputs to the serotonin and dopamine neuromodulatory systems. Cell Rep 8:1105-1118. CrossRef Medline

Philippart F, Destreel G, Merino-Sepúlveda P, Henny P, Engel D, Seutin V (2016) Differential somatic $\mathrm{Ca}^{2+}$ channel profile in midbrain dopaminergic neurons. J Neurosci 36:7234-7245. CrossRef Medline

Poetschke C, Dragicevic E, Duda J, Benkert J, Dougalis A, DeZio R, Snutch TP, Striessnig J, Liss B (2015) Compensatory T-type $\mathrm{Ca}(2+)$ channel activity alters D2-autoreceptor responses of substantia nigra dopamine neurons from Cav1.3 L-type Ca(2+) channel KO mice. Sci Rep 5:13688. CrossRef Medline

Poulin JF, Zou J, Drouin-Ouellet J, Kim KY, Cicchetti F, Awatramani RB (2014) Defining midbrain dopaminergic neuron diversity by single-cell gene expression profiling. Cell Rep 9:930-943. CrossRef Medline
Prensa L, Parent A (2001) The nigrostriatal pathway in the rat: a single-axon study of the relationship between dorsal and ventral tier nigral neurons and the striosome/matrix striatal compartments. J Neurosci 21:72477260. Medline

Puopolo M, Raviola E, Bean BP (2007) Roles of subthreshold calcium current and sodium current in spontaneous firing of mouse midbrain dopamine neurons. J Neurosci 27:645-656. CrossRef Medline

Regehr WG, Atluri PP (1995) Calcium transients in cerebellar granule cell presynaptic terminals. Biophys J 68:2156-2170. CrossRef Medline

Sando R 3rd, Baumgaertel K, Pieraut S, Torabi-Rander N, Wandless TJ, Mayford M, Maximov A (2013) Inducible control of gene expression with destabilized Cre. Nat Methods 10:1085-1088. CrossRef Medline

Schiemann J, Schlaudraff F, Klose V, Bingmer M, Seino S, Magill PJ, Zaghloul KA, Schneider G, Liss B, Roeper J (2012) K-ATP channels in dopamine substantia nigra neurons control bursting and novelty-induced exploration. Nat Neurosci 15:1272-1280. CrossRef Medline

Sharpe, A.L., Varela, E., Bettinger, L., and Beckstead, M.J (2014) Methamphetamine self-administration in mice decreases GIRK channel-mediated currents in midbrain dopamine neurons. Int J Neuropsychopharmacol pii:pyu073. CrossRef Medline

Shipe WD, Barrow JC, Yang ZQ, Lindsley CW, Yang FV, Schlegel KA, Shu Y, Rittle KE, Bock MG, Hartman GD, Tang C, Ballard JE, Kuo Y, Adarayan ED, Prueksaritanont T, Zrada MM, Uebele VN, Nuss CE, Connolly TM, Doran SM, et al. (2008) Design, synthesis, and evaluation of a novel 4-aminomethyl-4-fluoropiperidine as a T-type Ca2 + channel antagonist. J Med Chem 51:3692-3695. CrossRef Medline

Tsay D, Dudman JT, Siegelbaum SA (2007) HCN1 channels constrain synaptically evoked Ca2 + spikes in distal dendrites of CA1 pyramidal neurons. Neuron 56:1076-1089. CrossRef Medline

Wilson CJ, Callaway JC (2000) Coupled oscillator model of the dopaminergic neuron of the substantia nigra. J Neurophysiol 83:3084-3100. Medline

Wolfart J, Roeper J (2002) Selective coupling of T-type calcium channels to SK potassium channels prevents intrinsic bursting in dopaminergic midbrain neurons. J Neurosci 22:3404-3413. Medline

Xiang Z, Thompson AD, Brogan JT, Schulte ML, Melancon BJ, Mi D, Lewis LM, Zou B, Yang L, Morrison R, Santomango T, Byers F, Brewer K, Aldrich JS, Yu H, Dawson ES, Li M, McManus O, Jones CK, Daniels JS, et al. (2011) The discovery and characterization of ML218: a novel, centrally active T-type calcium channel inhibitor with robust effects in STN neurons and in a rodent model of Parkinson's disease. ACS Chem Neurosci 2:730-742. CrossRef Medline

Yamada T, McGeer PL, Baimbridge KG, McGeer EG (1990) Relative sparing in Parkinson's disease of substantia nigra dopamine neurons containing calbindin-D28K. Brain Res 526:303-307. CrossRef Medline

Yasuda R, Nimchinsky EA, Scheuss V, Pologruto TA, Oertner TG, Sabatini BL, Svoboda K (2004) Imaging calcium concentration dynamics in small neuronal compartments. Sci STKE 2004:pl5. Medline

Zeng H (2013) Generation of a destabilized EGFP/cre knockin allele of the Calb1 gene. MGI Direct Data Submission. MGI: J:202879.

Zhang TA, Placzek AN, Dani JA (2010) In vitro identification and electrophysiological characterization of dopamine neurons in the ventral tegmental area. Neuropharmacology 59:431-436. CrossRef Medline

Zheng N, Raman IM (2009) Ca currents activated by spontaneous firing and synaptic disinhibition in neurons of the cerebellar nuclei. J Neurosci 29: 9826-9838. CrossRef Medline 